\title{
TENTANG KERJA DAN PANGGILAN
}

\author{
Jadi S. Lima \\ STT Reformed Injili Internasional
}

\begin{abstract}
In this article, the author examining theological, philosophical and sociological aspects of work to understand it in Christian perspective. This analysis will be used to construct a suggestion of Christian work ethic that can be applied for this age. There are three sources that are considered in discussing the Christian work ethic: the bible, tradition and modern life situation.
\end{abstract}

KEYWORDS: Work, calling, meaning, eschatology, ontology, epistemology, ecclesiology, Augustine, Luther, Calvin, Volf, Pascal, Fermat.

ABSTRAK: Dalam artikel ini penulis melakukan kajian pada aspekaspek teologis, filosofis dan sosiologis dari pekerjaan untuk memahaminya secara Kristiani. Analisis ini akan dipakai untuk menyusun suatu usulan etika kerja Kristen yang dapat diterapkan pada zaman ini. Ada tiga sumber yang akan dipertimbangkan dalam mengulas etika kerja Kristen tersebut: alkitab, tradisi, dan situasi hidup modern.

KATA-KATA KUNCI: Kerja, panggilan, makna, eskatologi, ontologi, epistemologi, eklesiologi, Augustinus, Luther, Calvin, Volf, Pascal, Fermat.

\section{Pengantar}

Cara kita memaknai pekerjaan dan hal-hal lain dalam kehidupan selalu ditentukan oleh cara pandang dunia (worldview) kita. Cara pandang dunia itu sendiri, seperti kata Cliford Geertz selalu memiliki fokus ganda: yaitu sebagai vision of the world dan vision for the world. ${ }^{1}$ Yang pertama bersifat deskriptif (visi mengenai seperti apakah dunia itu),

\footnotetext{
1 James Olthuis, On Worldviews dalam Christian Scholar's Review, Vol. XIV, No. 2. Dokumen dapat diakses online pada situs http://www.freewebs.com/jamesolthuis/OnWorldviews.pdf.
} 
yang kedua normatif (visi untuk membentuk dunia ini). Karena itu kita akan membagi analisis menjadi dua, yaitu: 'Worldview' dan 'Konteks Sosial'. Yang pertama mewakili aspek deskriptif dari worldview sedangkan yang kedua mewakili aspek normatif-konstruktifnya. Setiap analisis akan terbagi menjadi dua tahap, yaitu: analisis permasalahan dan posisi teologis-filosofis yang diambil dalam permasalahan itu. Setelah bagian analisis, kita akan melakukan rekonstruksi suatu usulan tentang etika kerja Kristen yang didasarkan pada cara pandang alkitab dan sekaligus dapat diterapkan dalam situasi zaman ini.

\section{Worldview}

Di dalam artikel ini penulis akan mencoba untuk menunjukkan bahwa salah satu penyebab kegagalan orang Kristen dalam mengintegrasikan kerja-panggilan berakar pada ketidak-memadaian cara pandang kita terhadap pekerjaan. Di dalam interaksinya yang sangat rumit dengan pemikiran dan jejaring kehidupan dunia, kekristenan telah memakai beberapa macam kerangka teologis-filosofis yang tidak alkitabiah, yang akhirnya mengakibatkan kesulitan di dalam mengintegrasikan panggilan Tuhan dalam pekerjaan masing-masing pada zaman ini. Bagian ini memiliki dua tujuan, pertama: menunjukkan bagaimana kerangka teologis-filosofis yang dualistik akan memecahbelah integrasi antara panggilan Tuhan dan pekerjaan, kedua: merumuskan suatu usulan tindakan menuju pemulihan integrasi kerjapanggilan.

\section{Empat Problem Konseptual}

Cara pandang terhadap pekerjaan yang kurang memadai berakar pada empat kesalahan konseptual, yaitu: 1) Dualisme protologiskosmologis, 2) Dualisme epistemologis, 3) Dualisme eklesiologis, 4) Soteriologi, eskatologi dan konsep waktu yang tidak memadai. Keempat kesalahan ini bersifat timbal balik. Cara pandang terhadap semesta ciptaan Tuhan yang bersifat fragmental biasanya dapat ditelusuri kepada 
doktrin penciptaan yang bersifat dualistik. Kosmologi yang dualistik berasal dari protologi yang dualistik pula. Dualisme dalam kosmologi adalah penyebab dari pemisahan antara wilayah pengetahuan jasmani dan rohani, atau dalam epistemologi Kant: phenomena dan noumena. Pemisahan wilayah pengetahuan ini akhirnya menyebabkan aspek iman dalam kehidupan Kristen semakin tergusur ke wilayah privat dan menjadi masalah yang sangat other-worldly. Pemisahan dalam wilayah epistemologi ini memiliki dampak logis berupa pemisahan dua dunia antara imam (atau di kalangan gereja Injili di Indonesia lebih sering disebut 'hamba Tuhan') yang berurusan dengan alam noumena, dan 'kaum awam' yang selain memiliki 'jiwa' yang harus dipenuhi kebutuhan rohaninya, masih banyak berurusan dengan masalah-masalah pekerjaan 'sekular.' Dualisme imam-awam dalam eklesiologi (baik diakui secara terus terang, seperti pada Gereja Katolik Roma maupun tidak, seperti pada beberapa aliran Injili) akan menentukan pekerjaan apa saja yang dianggap dekat dengan 'kerajaan Allah' dan pekerjaan mana yang hanya berurusan dengan 'hidup sekarang' yang dianggap kurang berharga bagi kerajaan Allah, karena akan 'lenyap seperti uap.' Dualisme eklesiologis itu juga langsung disebabkan oleh asumsi protologi-kosmologinya, yang tentu saja dualistik. Aspek terakhir yang sangat menentukan cara kita memandang kerja (dan hidup) adalah konsep soteriologi, eskatologi dan waktu. Ketiga konsep terakhir ini berkaitan dengan pertanyaan, "Apa yang salah?" dan, "Bagaimana mengatasinya?" Ketiganya merupakan kerangka dasar tempat kita beraksi di dalam hidup ini. Apa dan bagaimana kita menjalani kehidupan kita saat ini, pilihan-pilihan apa saja yang kita ambil hari ini sangat ditentukan oleh cara kita memandang masa lalu, masa kini, dan masa depan. Dengan kata lain, konsep waktu dan eskatologi akan sangat menentukan etika, khususnya etika kerja.

Keempat konsep ini adalah pusat dari sistem worldview, sehingga menentukan jawaban atas empat pertanyaan dasar setiap orang: Siapakah saya, di manakah saya berada, apa yang salah, dan bagaimana 
mengatasi kesalahan itu. ${ }^{2}$ Kita akan memulai dari pertanyaan yang telah menjadi topik diskusi yang seru sebelum kelahiran Socrates, yaitu: kosmologi dan protologi. Yang pertama berkenaan dengan alam semesta sebagaimana adanya, sedangkan yang kedua berkenaan dengan asalusul semesta (yang telah dijawab oleh banyak penyair Yunani kuno dalam bentuk kisah penciptaan atau cosmogony).

\section{Dualisme Ontologis}

Cara kita memandang seluruh realitas tentu saja tak dapat dipisahkan dari keyakinan kita tentang asal-usul semesta (protologi) dan tentang struktur semesta itu sendiri (kosmologi). Ada beberapa alternatif yang telah dipakai orang sepanjang sejarah untuk menjelaskan asal-usul dan struktur semesta/realitas tempat kita berada. Alternatif-alternatif yang ada secara umum dapat digolongkan menjadi dua jenis, yaitu: monisme dan dualisme. Monisme berasumsi bahwa semesta/realitas pada dasarnya adalah satu (atau: merupakan satu kesatuan). Sedangkan dualisme berasumsi bahwa semesta tak mungkin dapat dijelaskan dari satu kesatuan seperti dilakukan oleh monisme. Minimal ada dua kekuatan atau substansi dasar yang membentuk atau menciptakan semesta.

Kedua cara pandang ini memiliki kesulitan masing-masing. Salah satu kesulitan monisme adalah: jika kejahatan dan kebaikan pada dasarnya adalah sama atau satu, kita akan sulit menjelaskan bagaimana Allah yang baik juga adalah sumber segala kejahatan. Agama-agama Timur yang umumnya menganut monisme memecahkan masalah ini dengan logika paradoksal atau mistisisme. Sang baik itu sekaligus adalah sang jahat. Tidak ada masalah di sini, karena baik dan jahat, seperti juga dengan semesta (mayapada), pada dasarnya adalah semu. Bagi orang yang telah mengalami pencerahan, ia akan dapat melihat bahwa sesungguhnya tidak ada perbedaan diantara baik dan jahat. Tidak

\footnotetext{
2 Brian J. Walsh \& J. Richard Middleton, Visi yang Membaharui (Jakarta: Reformed Institute Press, 2001), 40.
} 
demikian dengan dualisme. Karena dualisme berasumsi bahwa semesta pada dasarnya adalah dua, maka ia dapat menimpakan asal-usul kejahatan pada Sang Jahat dan asal-usul segala kebaikan pada Sang Baik. Tidak ada kontradiksi logis di sini. Mungkin itulah sebabnya agamaagama Barat, yang hampir pasti berinteraksi dengan Aristotle dan prinsip non-kontradiksinya, lebih banyak bersifat dualis seperti misalnya Manikheisme dan Zoroastrianisme. Walaupun dengan menimpakan segala kesalahan pada Sang Jahat dualisme dapat menghindari kesulitan dari problem of evil, tetapi ia memiliki kesulitan yang lain, yaitu: kehidupan yang fragmental. Di dalam cara pandang yang dualistik, fragmentasi kehidupan terjadi di dalam segala aspek, misalnya: dikotomi tubuh-jiwa, dikotomi material-spiritual, dikotomi kekekalankesementaraan, dikotomi imam-awam, dan dikotomi surga-bumi.

Kesulitan yang dialami monisme dan dualisme dapat dihindari jika kita memakai cara pandang alkitabiah dalam melihat semesta. Orang Kristen percaya bahwa alkitab mengatakan bahwa semesta diciptakan dan dipelihara keberadaannya oleh Allah Tritunggal. Jika kita memakai paradigma Tritunggal ini dalam memandang semesta, kita tak akan menemui jalan buntu sebagaimana dialami oleh monisme dan dualisme. Walaupun demikian, sepanjang sejarah orang Kristen telah menukarkan paradigma Tritunggal ini dengan dualisme atau monisme.

Dualisme protologis telah muncul dalam rupa pengajaran gnostisisme dalam masa para rasul dan itu berlanjut ke dalam bentuk kekristenan yang dipengaruhi neo-platonisme pada masa bapak-bapak gereja awal, dan Aristotelianisme sepanjang abad pertengahan. Problema dualisme ini masih terus berlangsung dalam tubuh kalangan fundamentalis sempit dalam rupa pemisahan kehidupan antara yang rohani dan sekular; kini-di sini dan nanti-di sana. Bagaimana perkembangan dualisme protologi-kosmologi sepanjang sejarah gereja? Hal ini dapat ditelusuri dengan melihat bagaimana para teolog gereja sepanjang zaman menafsirkan Kejadian 1 dan 2, dan bagaimana penafsiran ini melandasi kosmologi mereka. 
Dualisme dalam doktrin penciptaan adalah akar dari dualisme kosmologi, dan kosmologi yang dualistik menyebabkan terjadinya pelarian dari dunia 'sekarang-disini-material' yang sesungguhnya telah diapresiasi sebagai 'amat baik' oleh Sang Pencipta sendiri. Pelarian ini, dalam bahasa Kejadian 1-2, juga merupakan pelarian manusia dari tanggung jawabnya memelihara dan mengusahakan ciptaan.

Setelah modernisme menggeser peranan kekristenan dari panggung sejarah, ia tidak menyediakan jalan keluar yang memuaskan. Pemecahan yang ditawarkan cenderung menafikan hal-hal yang transenden, yang bersifat 'nanti-disana-imaterial.' Orang modern cenderung skeptis (kalau bukan negatif) terhadap hal-hal demikian. Hal ini didukung oleh sistem epistemologi Kant yang walaupun menyediakan ruang bagi hal-hal yang transenden tetapi menyangkali kemungkinan adanya pengetahuan tentang hal-hal itu. Sekarang kita akan melihat aspek epistemologis dari worldview.

\section{Dualisme Epistemologi}

Setelah Socrates para filsuf Yunani kuno mengalihkan pembicaraan dari kosmologi ke epistemologi. Dari semesta di luar diri manusia ke proses mengetahui yang dialami manusia pencari kebenaran itu sendiri. Sebelum Socrates orang tak pernah mempermasalahkan keabsahan pengetahuan atau narasi-narasi kosmogonik tentang penciptaan semesta. Socrateslah yang mengajak kita untuk mulai memikirkan ulang kebenaran yang selama ini telah diterima dengan begitu saja oleh banyak orang. Dalam zamannya, Socrates mengajak orang untuk juga memikirkan ulang konsep yang telah diterima berabadabad tentang para dewa yang mengatur kehidupan di bumi. Dengan demikian Socrates mengajak kita untuk dengan berani berpikir bagi diri kita sendiri, tidak menerima dengan begitu saja pengetahuan yang diberikan kepada kita oleh orang lain ataupun tradisi. Bagi Socrates pencarian kebenaran sejati ini bersifat introspektif. Ia percaya bahwa manusia secara intrinsik memiliki pengetahuan itu di dalam dirinya, 
hanya saja kemudian pengetahuan sejati ini dikaburkan oleh pengetahuan palsu yang belum diuji dengan rendah hati. Dalam bagian ini kita hanya akan melihat bagaimana epistemologi Kantian telah menyangkali kemungkinan orang untuk memiliki pengetahuan yang bersifat universal tentang hal-hal yang transenden. Dengan demikian halhal yang transenden tak lagi dapat menjadi pijakan bagi etika publik.

Kita tak dapat melepaskan pemikiran Kant dari proyek besar Enlightenment, yaitu membebaskan manusia dari belenggu 'masa kanakkanak' yang diwakili oleh otoritas-otoritas non-rasional, seperti: gereja, tradisi, dan adat-istiadat. Kant mengatakannya pada artikel What is Enlightenment?

Enlightenment is man's emergence from his self-imposed nonage. Nonage is the inability to use one's own understanding without another's guidance. This nonage is self-imposed if its cause lies not in lack of understanding but in indecision and lack of courage to use one's own mind without another's guidance. Dare to know! (Sapere aude.) "Have the courage to use your own understanding," is therefore the motto of the enlightenment. ${ }^{3}$

Pada masa-masa sebelum Enlightenment otoritas religius memiliki kekuatan yang sangat besar karena berafiliasi dengan para penguasa politik. Otoritas religius yang hampir mutlak ini seringkali disalahgunakan untuk menindas rakyat demi kepentingan penguasa, atas nama 'kebenaran Tuhan.' Hal demikian dapat kita amati di dalam perdebatanperdebatan di parlemen Inggris antara para penguasa yang sama-sama mengaku dapat mengetahui kehendak Tuhan secara pribadi. ${ }^{4}$ Dengan demikian para pemikir Enlightenment yang menganjurkan rasio sebagai kriteria final penentu kebenaran, seperti Locke, sesungguhnya ingin membebaskan publik dari penyalah-gunaan otoritas dengan mengatasnamakan Tuhan dan Alkitab. Bagaimana kita dapat sama-sama

\footnotetext{
3 Immanuel Kant, What is Enlightenment? Terjemahan Inggris dari Mary C. Smith dapat diakses dalam situs http://www.columbia.edu/acis/ets/CCREAD/etscc/kant.html

4 Anthony C. Thiselton, Interpreting God and the Postmodern Self: On Meaning, Manipulation and Promise (Grand Rapids: Eerdmans, 1995), 4.
} 
memeriksa kebenaran sebuah pernyataan kalau bukan dengan rasio? Inilah alasan di balik kelahiran rasionalisme.

Epistemologi yang dualistik ini adalah salah satu penyebab utama dari privatisasi agama dalam masyarakat modern. Jika benar salah dalam hal-hal transenden tak lagi diakui universalitasnya memang kita tak lagi memiliki dasar epistemologis bagi manipulasi atas nama Tuhan atau perang antar agama, tetapi dunia publik juga kehilangan bobot ultimatnya. Tetapi keuntungan ini nampaknya kini tak lagi dapat kita nikmati karena dua faktor. Yang pertama adalah fakta kebangkitan fundamentalisme. Apakah kita dapat hidup bersama tanpa kehadiran Sang Transenden didunia publik? Samuel Huntington menyatakan kemustahilan hal ini. ${ }^{5}$ Nilai-nilai peradaban (dan agama adalah pusat setiap peradaban) lebih kuat daripada nilai-nilai ideologi 'universal' racikan Aufklarung. Perbenturan peradaban tak dapat dihindari. Faktor kedua adalah runtuhnya mitos tentang netralitas sains. Orang, termasuk para saintis yang dahulu sangat confident dengan metode ilmiah yang dianggap netral dan mampu menghasilkan pengetahuan universal dan bebas nilai, tak lagi mempercayai mitos tentang kenetralan sains dan universalitas kebenaran ilmiah. Thomas Kuhn berhasil menunjukkan bahwa revolusi sains tak pernah terpisah dari presuposisi atau paradigma setiap zaman. ${ }^{6}$ Tidak ada observasi yang netral. Michael Polanyi dalam Tacit Dimension dan Personal Knowledge menunjukkan bahwa sains sebenarnya adalah pencarian kebenaran yang bersifat sangat personal, karena kita sesungguhnya selalu mengamati dengan suatu cara pandang yang telah diwarnai kecenderungan-kecenderungan personal tertentu. Dapat dikatakan pengetahuan tidak dimungkinkan tanpa adanya komitmen sebelumnya. Hal ini menjadikan sains sebagai kegiatan iman. Dalam hal ini Paul Tillich benar ketika ia mendefinisikan

\footnotetext{
5 Samuel P. Huntington, The Clash of Civilizations and Remaking of World Order (NY: Simon Schuster, 1996), 31-35.

6 Nancy R. Pearcey, The Soul of Science: Christian Faith and Natural Philosophy (Wheaton: Crossway, 1994), 48-49, dan J. Wentzel van Huyssteen, Teologi dan Sains dalam Dunia PostModern: Duet atau Duel? (Jakarta: BPK, 2000), 9-13.
} 
agama sebagai "kedalaman (depth) dari semua fungsi dalam kehidupan spiritual manusia."7 Tillich mendefinisikan metafor depth ini sebagai ultimate concern (yaitu yang bersifat ultimate, infinite, dan unconditional) dalam jiwa manusia. Ultimate concern ini termanifestasi dalam semua fungsi kreatif manusia. ${ }^{8}$ Dalam moral sebagai tuntutan moral, dalam kognitif sebagai kehausan akan ultimate reality, dalam estetika sebagai kerinduan untuk mengekspresikan ultimate meaning. ${ }^{9}$ Agama adalah ultimate seriousness dalam hidup manusia yang menjadi substansi dari perwujudan keberadaan manusia. Agama adalah substansi setiap aktivitas manusia baik secara privat maupun publik.

Rangkaian aktivitas manusia itu membentuk jejaring peradaban yang lazim disebut sebagai 'kebudayaan.' Dengan demikian budaya adalah bentuk (form) dari agama. Tillich memberikan contoh dengan menunjuk sebuah fakta bahwa agama selalu saja diekspresikan dan dikomunikasikan dengan menggunakan bahasa. Agama tidak pernah dapat lepas dari bahasa. ${ }^{10}$ Sedangkan bahasa adalah produk budaya yang diubah oleh apa yang diekspresikannya (dalam kasus bahasa agama, agama membentuk bahasa yang dipakainya). Jadi jelas bahwa agama pasti mengambil rupa budaya, dan dengan demikian tidak dapat dilepaskan dari dunia publik. Dengan demikian agama menjadi substansi pemberi makna pada budaya, setiap religious act adalah gerakan jiwa yang paling intim. ${ }^{11}$ Sekarang kita akan melihat ke dalam permasalahan yang terjadi sewaktu orang kristen memakai konsep yang tidak alkitabiah dalam berhubungan satu sama lain sebagai gereja.

\section{Dualisme Eklesiologi}

Salah satu kesalahan epistemologis yang membuat orang Kristen sulit untuk mengintegrasikan panggilan dan kerja adalah dualisme

\footnotetext{
Paul Tillich, Theology of Culture (NY: Oxford Univ. Press, 1959, 1964), 7.

8 Ibid., 8.

$9 \quad$ Ibid., 8.

$10 \quad$ Ibid., 47.

11 Ibid., 42.
} 
dalam eklesiologi. Yang dimaksud dengan dualisme eklesiologis adalah pemisahan yang dilakukan dalam tubuh Kristus antara kalangan pelayan (clergy/minister) dan yang dilayani (layman). Pemisahan ini biasanya tidak diakui karena dipandang buruk, tetapi ciri-ciri yang ada membuktikan bahwa pemisahan seperti ini sesungguhnya terjadi.

Pemisahan antara 'imam' dan 'awam' kemungkinan besar berakar pada perlunya wakil Allah di bumi (Deus terrenus) untuk mempersatukan umat. Konsep ini adalah titik mula ajaran tentang hirarki kepausan dalam gereja yang bertolak dari formulasi Ignatius dari Antiokia (meninggal 104 AD), "Satu Allah, satu Kristus, satu uskup, satu jemat lokal." 12 Leonardo Boff, berpendapat bahwa hirarki piramidal pemerintahan gereja yang memisahkan 'imam' dan 'awam' ini berakar pada kelalaian untuk menimbang ajaran perichoresis dalam diri Tritunggal. ${ }^{13}$ Ini merupakan warisan monoteisme atrinitatis yang akan menghasilkan diktatorisme para imam dan kepasifan kaum awam dalam pelayanan. ${ }^{14}$

Perjanjian Baru tidak pernah mengajarkan hirarki eklesiologis. Hal ini dapat diindikasikan oleh struktur pemerintahan gereja dalam suratsurat Paulus yang beragam. Tidak ada hirarki yang baku. Seperti dikatakan Ernst Kasemann dalam Paul and Early Catholicism,

...Gereja yang "ideal", yang menjadi nyata dalam intisari tulisan-tulisan Paulus, adalahgereja yang memandang karunia-karunia, dan bukan jabatan-jabatan, sebagai tanda yang membedakan di antara orang Kristen dan gereja yang di dalamnya Roh Tuhan mengikat orang Kristen bersama-sama di bawah ketuhanan Kristus, "Dengan jelas dapat dikatakan, tanpa membesar-besarkan, jemaat-jemaat paulus bukan terdiri atas siapa-siapa, melainkan hanyalah kaum awam yang, di dalam kesempatan mereka, bertindak pada saat yang sama sebagai imam dan pejabat pemerintahan (gerejawi), yakni alat-alat Roh untuk mewartakan Injil dalam dunia sehari-hari."15

\footnotetext{
12 Leonardo Boff, Allah Persekutuan: Ajaran tentang Allah Tritunggal (Maumere: LPBAJ, 1999), 30.

13 Ibid., 22-34.

14 Ibid., 22-34.

15 Sebagaimana dikutip oleh David L. Bartlett, Pelayanan dalam Perjanjian Baru (Jakarta:
} 
Bahkan rasulpun tidak memerintah atas jemaat dengan paksa, walaupun ia berhak untuk itu. Hal ini dapat kita lihat dari cara Paulus meminta (bukan memerintah) kepada Filemon agar menerima kembali Onesimus. ${ }^{16}$

Dalam bagian 'Biblical Worldview' kita akan melihat bahwa eklesiologi yang alkitabiah haruslah didasarkan pada perichoresis antar pribadi Tritunggal, sebagaimana doa Kristus bagi kita,

... juga untuk orang-orang yang percaya kepada-Ku oleh pemberitaan mereka; supaya mereka semua menjadi satu, sama seperti Engkau, ya Bapa, di dalam Aku dan Aku di dalam Engkau, agar mereka juga di dalam Kita, supaya dunia percaya, bahwa Engkaulah yang telah mengutus Aku ... dan bahwa Engkau mengasihi mereka sama seperti Engkau mengasihi Aku. ${ }^{17}$

\section{Soteriologi, Eskatologi, \& Konsep Waktu}

Bagian ini akan menggumuli tema yang berkaitan dengan waktu, yaitu: soteriologi, eskatologi, dan pandangan tentang waktu itu sendiri. Yang dimaksudkan dengan 'soteriologi' di sini adalah cara manusia menjawab pertanyaan dasar, "Bagaimana penyelesaian masalahnya?" dalam sistem cara pandang dunianya. Jadi ini tidak hanya meliputi soteriologi Kristen saja, tetapi juga akan meliputi soteriologi Marxisme, Epicureanisme, sampai Gnostisisme. Pembahasan mengenai soteriologi tidak akan dapat dilepaskan dari kosmologi-protologi, epistemologi, dan konsep waktu.

Dalam survey sejarah kita melihat bahwa selama ribuan tahun kekristenan dihantui oleh kosmologi yang terbelah. Dalam kosmologi yang terbelah, keselamatan selalu berarti "diselamatkan dari" yang hampir selalu berarti "dipindahkan kepada alam yang lain." Hal ini mengakibatkan dalam sepanjang sejarah kekristenan (kecuali di dalam

BPK, 2000), 35.

16 Flm. 1:8-9 “Karena itu, sekalipun di dalam Kristus aku mempunyai kebebasan penuh untuk memerintahkan kepadamu apa yang harus engkau lakukan, tetapi mengingat kasihmu itu, lebih baik aku memintanya dari padamu."

17 Yoh. 17: 20b-21, 23b. 
Calvinisme) soteriologi kita bersifat pelarian. Walaupun tidak semua aliran memiliki asketisme yang bersifat extra mundane, hampir semuanya setidaknya memberikan tempat yang lebih rendah kepada kegiatankegiatan yang berkaitan dengan 'kini dan di sini.' Aktivitas menyapu lantai misalnya, seringkali dipandang lebih rendah daripada berkhotbah, karena berkaitan dengan kesementaraan dan 'dunia sini.' Walaupun para Bapak gereja seperti Augustine, Thomas Aquinas, bahkan Thomas a Kempis memang memandang pekerjaan fisik seperti menyapu dapat berguna bagi kerohanian kita, yaitu sebagai 'bangunan bawah yang mendukung struktur di atasnya' dan sebagai latihan kerendahan hati, tetapi tetap saja pekerjaan itu sendiri tak memiliki nilai intrinsik. Para pemikir kemudian mengangkat pekerjaan ke taraf yang lebih tinggi. Luther misalnya, memang telah mengangkat 'aktivitas duniawi' ke dalam tingkatan yang setara dengan 'aktivitas rohani,' tetapi Luther cenderung hanya memandangnya secara personal atau inter-personal. ${ }^{18}$ Kerja berguna untuk memenuhi kebutuhan sesama, dan karena itu kerja dapat menjadi sarana pelayanan kasih kita pada sesama. Tetapi saya ingin menambahkan catatan berkenaan dengan kontribusi Luther di sini: kita perlu ingat bahwa pada mulanya Tuhan menempatkan kita di bumi ini untuk "mengusahakan dan memelihara" taman Eden, dalam rangka memuliakan Tuhan sebagai peta dan teladan Sang Raja semesta alam. Relasi inter-personal adalah bagian dari visi besar ini. Tuhan menempatkan orang lain sebagai penolong untuk mencitrakan Tuhan dengan mengusahakan ciptaan. Seperti dikatakan Paul Marshall dalam Heaven is not My Home,

God made human being precisely in order to care for the earth. We were made to serve this purpose. It is built into our very being; it is our very design ... If we do not take up our responsibility for God's world, we defy

\footnotetext{
18 Martin Luther, Martin Luther's Werke, 42, 640 sebagaimana dikutip oleh Miroslaf Volf dalam Work in the Spirit (Oxford: OUP, 1991), 108.
} 
not only His command, but also our very nature and the very purpose for which we have been created. ${ }^{19}$

Kegagalan melihat signifikansi kerja fisik (di luar yang berkenaan dengan dimensi inter-personal) di dalam dunia telah membawa kita memiliki konsep soteriologi yang bersifat extra mundane. Cara pandang seperti ini sebenarnya telah menyempitkan penebusan hanya pada aspek rohani dan kekal saja. Hal ini dapat dirunut pada pandangan tentang khasiat salib yang tidak meliputi seluruh ciptaan, tetapi hanya beberapa aspek. Penebusan Tuhan di kayu salib akhirnya hanya dipandang semata sebagai membawa manusia keluar dari situasi yang berbahaya, dalam hal ini adalah dunia yang telah tercemar dosa. Dunia yang berdosa itu sendiri dibiarkan binasa di dalam penghakiman Tuhan nanti. Jika dunia dipandang hanya sebagai padang gurun yang sekedar kita lewati dalam perjalanan ke Kanaan, maka kita tak perlu berbuat apapun pada padang gurunnya sendiri selain berharap dapat melewatinya secepatnya. Pandangan tentang dunia sebagai 'padang gurun' bermula dari pembacaan alegoris dari Augustine atas perjalanan umat Israel keluar dari Mesir. ${ }^{20}$ Untung saja seorang Reformator yang meminjam

19 Paul Marshall, Heaven is not My Home: Living in the Now of God's Creation (Nashville: Word Publishing, 1998), 18.

20 Walaupun dalam menggambarkan perjalanan orang percaya sebagai musafir yang melewati padang gurun, Augustinus bukan terutama menekankan mengenai kegersangannya, tetapi bahwa itu adalah perjalanan maju menuju suatu tempat yang lebih baik. Bukan kembali ke taman Eden. Ini adalah inovasi Augustinus yang telah dapat ditemukan dalam karya-karya Ambrose, tetapi merupakan arah baru dalam teologia di zamannya yang cenderung memandang bahwa eskatologi kita menuju 'rumah semula' yaitu taman Eden.

Crouse mengatakan tentang hal ini "In this view, the paradisal image of reform means something different: not the return to the pristine integrity of Eden, however spiritually conceived. The integrity of Eden is not the pilgrim's destination: In melius renovabimur, says St. Augustine, "we shall be changed into something better" (selanjutnya dapat dibaca di http://stpeter.org/crouse/writings/pilgrimage_chap_4.htm). Di sisi lain, memang di dalam Alkitab ada juga penggambaran dunia ini sebagai kesementaraan, sebagai fase yang akan lewat. Tetapi di dalam mengatakan hal-hal demikian Alkitab biasanya memakai istilah 'dunia' sebagai struktur yang dibuat manusia untuk melawan kehendak Tuhan, dan bukan struktur ciptaan sendiri (mis. 1Yoh. 2: 15).

Peter Davies berkomentar mengenai penggunaan istilah ini: "Yohanes menggunakan istilah ini enam kali dalam 1Yoh. 2:15-17, tetapi ia juga menggunakannya tujuh belas kali dalam 13 Yoh.. Dunia dalam Kitab 1 Yoh. bukanlah planet atau ciptaan, melainkan lingkungan di 
soteriologi Augustine di zaman renaissance tidak mengikuti pandangan Augustine yang kelewat negatif dan berat sebelah terhadap dunia ini. Ia memandang dunia dan kerja manusia di dalamnya secara tepat sebagai pancaran kemuliaan Allah dalam semesta ciptaan yang dinilai oleh Tuhan sendiri sebagai, 'sungguh amat baik.' Orang itu bernama John Calvin. Mengenai dunia material dan peranan manusia di dalamnya Calvin mengatakan dalam tafsiran Mazmur 104: 1-2:

It is no small honor that God for our sake so magnificently adorned the world, in order that we may not only be spectators of this bounteous theater, but also enjoy the multiplied abundance and variety of good things which are presented to us in it. ${ }^{21}$

Dalam komentarnya tentang Mazmur 104: 1-2 Calvin mengatakan bahwa alam ciptaan ini adalah pakaian kebesaran di mana Tuhan sendiri yang tak terlihat menyatakan diri-Nya.

in respect of his essence, God undoubtedly dwells in light that is inaccessible; but as he irradiates the whole world by his splendor, this is the garment in which he, who is hidden in himself, appears in a manner visible to us. ${ }^{22}$

\footnotetext{
mana kita hidup. Dengan demikian dunia itu berarti keseluruhan budaya dan lembaga manusia, masyarakat secara kolektif. Masyarakat itu dikendalikan oleh Iblis (1Yoh. 5: 19; bandingkan 4:4). Itulah sebabnya masyarakat tersebut bermusuhan dengan Allah dan orang-orang yang mengikut Dia (3:13). Sesungguhnya, "dunia" adalah tempat tujuan nabinabi palsu ketika mereka meninggalkan gereja $(4: 1,3,5)$. Hal ini berbeda dengan pengertian "dunia" dalam Yohanes 3:16, di mana "dunia" yang dikasihi Allah berarti umat manusia, dan bukan budaya dan lembaga yang telah kita ciptakan. Kata "dunia" dalam 1Yoh. memusatkan perhatian pada budaya manusia, yang pada dasarnya berrnusuhan dengan Allah." Lih. Peter H. Davids, Ucapan yang Sulit Dalam Perjanjian Baru, (Malang: Penerbit SAAT), 249-252.

Penulis memakai pembedaan antara dua sense dari istilah 'dunia' dan 'dunia yang sekarang' ini dalam memberikan penilaian mengenai bagaimana kita sebaiknya membaca sisi 'other worldly' dari John Calvin sebagaimana biasa dikutip dari tulisannya, Of Meditating on the Future Life dari Institutes buku ke 3 bab ke 9.

21 Tafsiran dari Mazmur 104:31, dikutip dalam Randall A. Zachman, "The Universe as the Living Image of God: Calvin's Doctrine of the Universe Reconsidered" dalam Concordia Theological Quarterly (Vol. 61: No. 4, tahun 1997), 303.

22 Tafsiran dari Mazmur 104: 1-2, dikutip dalam Zachman, "The Universe as the Living Image of God: Calvin's Doctrine of the Universe Reconsidered", 306.
} 
Calvin melihat ciptaan sebagai semacam lukisan yang menyatakan kekuatan dan hikmat Tuhan bagi manusia agar mereka mengakui kedaulatannya dan mendapatkan kebahagiaan.

We must therefore admit that in God's individual works-but especially in them as a whole - that God's powers are actually represented as in a painting. Thereby the whole of mankind is invited and attracted to recognition of him, and from this to true and complete happiness. ${ }^{23}$

Setelah mengatakan sisi 'this worldly' dalam spiritualitas Calvin, tentu saja kita tak boleh melupakan bahwa Calvin juga menulis "Of Meditating on the Future Life" di dalam Buku ke-3 bab ke-9 dari Institutes di mana kita mendengar nada yang lebih suram tentang 'dunia yang sekarang ini' dan peringatan agar kita tidak 'terlalu mencintai kehidupan yang sekarang ini'. Bahkan bagi Calvin tak ada jalan yang separoh-separoh, kita harus memilih antara mencintai dunia yang sekarang ini atau menganggapnya 'sampah' (worthless) agar kita menghargai apa yang sungguh bernilai, yaitu dunia yang akan datang.

For there is no medium between the two things: the earth must either be worthless in our estimation, or keep us enslaved by an intemperate love of it. Therefore, if we have any regard to eternity, we must carefully strive to disencumber ourselves of these fetters. Moreover, since the present life has many enticements to allure us, and great semblance of delight, grace, and sweetness to soothe us, it is of great consequence to us to be now and then called off from its fascinations. ${ }^{24}$

Dalam Section 4, Calvin menulis bagaimana kita seharusnya mempersepsi 'kehidupan yang sekarang ini' jika dibandingkan dengan 'yang akan datang':

Let believers, then, in forming an estimate of this mortal life, and perceiving that in itself it is nothing but misery, make it their aim to exert themselves with greater alacrity, and less hinderance, in aspiring to the future and eternal life. When we contrast the two, the former may not only

\footnotetext{
23 John Calvin, Institutes of Christian Religion, terj. Henry Beveridge (Edinburgh: The Calvin Translation Society, 1845) Book I, Chapter V, Section 10.

24 Ibid., Book III, Chapter 9, Section 2.
} 
be securely neglected, but, in comparison of the latter, be disdained and contemned. If heaven is our country, what can the earth be but a place of exile? If departure from the world is entrance into life, what is the world but a sepulchre, and what is residence in it but immersion in death? If to be freed from the body is to gain full possession of freedom, what is the body but a prison? If it is the very summit of happiness to enjoy the presence of God, is it not miserable to want it? But "whilst we are at home in the body, we are absent from the Lord," (2Co 5: 6). Thus when the earthly is compared with the heavenly life, it may undoubtedly be despised and trampled under foot. ${ }^{25}$

Dalam kutipan di atas kita seperti melihat sosok yang terlihat berbeda dari Calvin yang menulis tafsiran dari Mazmur 104 sebagaimana kita kutip sebelumnya. Di sini Calvin membandingkan kehidupan kita di bumi ini sebagai 'pembuangan', bukan sekedar sebagai 'padang gurun' tetapi lebih buruk lagi, sebagai 'kuburan'. Mengenai tubuh, di sini Calvin menggambarkannya sebagai 'penjara' dan kehidupan di sini sebagai 'kematian'.

Still let us ardently long for death, and constantly meditate upon it, and in comparison with future immortality, let us despise life, and, on account of the bondage of sin, long to renounce it whenever it shall so please the Lord.

Apakah kita berhadapan dengan 'dua Calvin' yang tidak konsisten di sini? Satu Calvin mendorong kita untuk menghargai dunia ini sebagai pancaran kemuliaan Allah dan pekerjaan manusia di bumi sangat penting untuk berbagian dalam kemuliaan tersebut, sedangkan yang lain adalah Calvin yang mendorong kita seperti para Mistikus Abad Pertengahan unseperti tuk 'menyampahkan' dunia ini? Saya kira hanya ada satu Calvin saja yang konsisten dalam hal ini jika saja kita membaca tulisannya secara lebih teliti di dalam konteksnya. Di dalam chapter "Of Meditating on the Future Life" Calvin memang mengajak kita untuk 'merindukan kematian', secara terus menerus 'merenungkan kematian', bahkan ia menganjurkan kita untuk 'contempt' kehidupan yang sekarang ini dan merindukan untuk 'menanggalkannya' tetapi ajakan ini dibingkai

25 Ibid., Book III, Chapter 9, Section 4. 
dengan empat hal, yakni: Pertama, ada konteks 'kesulitan hidup' dan 'pencobaan' di dalam tulisan ini (lih. Section 1, "Whatever be the kind of tribulation with which we are afflicted ..."). Jadi ini bukan mengenai nilai dari benda-benda ciptaan itu sendiri, tetapi mengenai sikap kita terhadap hal-hal yang ada dalam 'ordo kesementaraan' ini. Kedua, contoh-contoh yang diangkat Calvin mengenai kebahayaan untuk 'terlampau mencintai' segala kebaikan dalam hidup yang sekarang ini terkait dengan dosa. Sebagai contoh, Calvin mengatakan di dalam Sect. 1 “... our minds being dazzled with glare of wealth, power and honors ... the heart also, engrossed with avarice, ambition, and lust, is weighed down and cannot rise above them." Calvin tidak mengatakan bahwa 'hal-hal duniawi' itu sendiri, sebagai ciptaan Allah, adalah buruk atau kurang nilainya, ataupun harus dipandang rendah, tetapi ia mengatakan bahwa hal-hal demikian dapat menyilaukan mata batin kita. Perlu dicatat di sini bahwa Calvin mengatakan bahwa dunia 'dapat menyilaukan' - ia tidak mengatakan bahwa hal-hal itu 'pasti menyilaukan'. Mata batin kita akan 'silau' dengan pesona kemuliaan palsu dunia ini jika hati kita terikat oleh dosa-dosa yang ia sebutkan itu: avarice, ambition and luist. Contoh yang diberikan Calvin mengenai manisnya pernikahan yang dapat menjerat kita dari merindukan dunia yang akan datang itu juga berkaitan dengan 'vainglory' yang terkandung di dalam sikap 'indulge too complacently in the advantages of married life'. Jadi Calvin tidak mengatakan kemakmuran, kekuasaan, kehormatan dan manisnya pernikahan itu sendiri harus direndahkan nilainya, tetapi harus diwaspadai karena ada terkandung bahaya dosa avarice, ambition, lust dan vainglory di dalam hal-hal tersebut jika kita mempraktikkan sikap yang salah dalam menghayatinya (yaitu: bukan sebagai ucapan syukur). Ketiga, Calvin memperingatkan agar sikap 'contempt' yang dikembangkan orang percaya terhadap dunia ini jangan merosot menjadi 'hatred of it' atau 'ingratitude to God' (section 3). Hidup yang sekarang ini, seberapapun buruknya, adalah berkat dari Tuhan yang tak boleh dihinakan. 
This life, though abounding in all kinds of wretchedness, is justly classed among divine blessings which are not to be despised. Wherefore, if we do not recognize the kindness of God in it, we are chargeable with no little ingratitude towards him. ${ }^{26}$

Keempat, kita perlu bertanya, keburukan macam apakah yang Calvin maksudkan ketika ia membandingkan 'dunia yang sekarang' dengan 'dunia yang akan datang'? Apakah ia sedang memikirkan mengenai buruknya material pembentuk daging manusia atau desain dari ciptaan yang terbatas atau pendeknya umur kita? Saya kira hal ini dapat kita lihat pada section 6 dari Meditasi itu.

On the other hand, when once they have raised their head above all earthly objects, though they see the wicked flourishing in wealth and honour, and enjoying profound peace, indulging in luxury and splendour, and revelling in all kinds of delights, though they should moreover be wickedly assailed by them, suffer insult from their pride, be robbed by their avarice, or assailed by any other passion, they will have no difficulty in bearing up under these evils. They will turn their eye to that day, (Isa 25: 8; Rev 7: 17), on which the Lord will receive his faithful servants, wipe away all tears from their eyes, clothe them in a robe of glory and joy, feed them with the ineffable sweetness of his pleasures, exalt them to share with him in his greatness; in fine, admit them to a participation in his happiness. But the wicked who may have flourished on the earth, he will cast forth in extreme ignominy, will change their delights into torments, their laughter and joy into wailing and gnashing of teeth, their peace into the gnawing of conscience, and punish their luxury with unquenchable fire. He will also place their necks under the feet of the godly, whose patience they abused. ${ }^{27}$

Penderitaan yang dimaksudkan Calvin akan terhiburkan oleh ingatan akan 'masa depan' itu rupanya adalah penderitaan akibat dosa, terutama ketika kita menjadi korban dari serangan orang-orang fasik, baik itu berasal dari penghinaan oleh sebab keangkuhan mereka, pemiskinan atau perampokan oleh keserakahan mereka, atau oleh ruparupa hawa nafsu jahat dari orang-orang fasik yang menimpa orang benar

\footnotetext{
26 Ibid., Book III, Chapter 9, Section 3.

27 Ibid., Book III, Chapter 9, Section 6.
} 
secara 'tidak adil' - di sinilah menurut Calvin ingatan akan 'hari pembalasan Tuhan' di masa mendatang itu akan menghibur kita. Demikian argumentasi saya bahwa apa yang dimaksudkan Calvin dalam tulisan ini dengan 'kehidupan yang sekarang' dan 'kelak' tidaklah melulu dapat dibaca sebagai perbandingan antara 'bumi' dengan 'langit' atau 'tubuh' dengan 'jiwa' dalam arti 'materi' dan 'non-materi', melainkan perbandingan antara ketidaksempurnaan atau 'kebelumsempurnaan' kehidupan yang sekarang, dimana kita masih berjuang melawan dosa dengan kehidupan yang akan datang di mana dosa, penderitaan, air mata, dan ketidakadilan telah sepenuhnya dilenyapkan oleh Tuhan. Dengan demikian menurut hemat penulis bagian ini dari Institutes tak dapat dipahami untuk membenarkan pandangan yang melihat ciptaan kurang dari segala kemuliaannya sebagai pakaian kebesaran Tuhan dan teater dari kekuasaan dan kemuliaan-Nya dimana manusia diberikan mandat untuk mengelola bumi sebagai panggilannya yang tertinggi. Pertanyaan yang penulis ajukan kepada para pembaca John Calvin yang ingin menyajikan sosok Calvin yang 'other-worldly' berdasarkan tulisan On Meditating of Future Life adalah ini: "Apakah ajakan Calvin untuk melihat 'kehidupan yang sekarang' sebagai suatu kerendahan jika dibandingkan dengan kecemerlangan dari 'kehidupan yang akan datang' berkaitan terutama dengan aspek ontologis dari eksistensi kita (bahwa kita ini material) ataukah dengan aspek moral (adanya kejahatan)?" Dalam bahasa Neo-Calvinis saya dapat mengajukan pertanyaan yang sama sebagai berikut: "Apakah kerendahan kehidupan yang sekarang ini menurut Calvin berkenaan dengan struktur ciptaan atau arahnya?" Sampai di sini orang dapat mengatakan bahwa tentu saja Calvin juga mengatakan sesuatu (bersama-sama dengan Paulus) tentang 'tubuh yang dapat binasa' ini dibandingkan dengan 'ketidakbinasaan' kita kelak, tetapi pada poin inipun saya kira Calvin tidak sedang membela pandangan tentang tubuh kebangkitan yang imaterial dan merupakan diskontinuitas dari eksistensi ciptaan pada masa kini. Dari contoh-contoh yang diberikan mengenai bagaimana orang percaya seharusnya waspada 
dan tabah terhadap 'sukacita dan kesengsaraan kita di masa kini' sudah jelas Calvin mengatakannya dalam kaitan dengan arah dan sasaran dari ciptaan. Sukacita pernikahan dan kemuliaan jabatan dapat memupuk vainglory, greed, pride dan lust di satu sisi, sehingga kita perlu untuk memuji Tuhan karena Ia memberikan salib pada hal-hal itu (seperti ketidakpuasan dengan pasangan atau anak-anak yang bejat), tetapi halhal 'duniawi' tersebut juga, menurut Calvin, tak boleh dihinakan, karena Allah yang telah melahirkan kita ke dalam dunia memberikan berkatberkatnya untuk dinikmati dengan ucapan syukur dan diperjuangkan sebagai bentuk rasa syukur kita melalui hal-hal tersebut juga. ${ }^{28}$

Tradisi Calvinis yang sangat positif dalam melihat dunia sebagai ciptaan Allah dan kerja sebagai panggilan ilahi bagi H. Richard Niebuhr termasuk dalam tipe converters of culture, ${ }^{29}$ melihat pekerjaan penebusan lebih luas daripada penebusan yang dikerjakan di dalam kematian, kebangkitan dan kedatangan terakhir Kristus saja. ${ }^{30}$ Mereka melihat pekerjaan penebusan Tuhan di dalam seluruh masa inkarnasi Kristus. Akibatnya,

28 Dalam section 3 meditasi ini Calvin mengatakan, "Still the contempt which believers should train themselves to feel for the present life, must not be of a kind to beget hatred of it or ingratitude to God. This life, though abounding in all kinds of wretchedness, is justly classed among divine blessings which are not to be despised. Wherefore, if we do not recognize the kindness of God in it, we are chargeable with no little ingratitude towards him. To believers, especially, it ought to be a proof of divine benevolence, since it is wholly destined to promote their salvation. Before openly exhibiting the inheritance of eternal glory, God is pleased to manifest himself to us as a Father by minor proofs, viz., the blessings which he daily bestows upon us. Therefore, while this life serves to acquaint us with the goodness of God, shall we disdain it as if it did not contain one particle of good? We ought, therefore, to feel and be affected towards it in such a manner as to place it among those gifts of the divine benignity which are by no means to be despised. Were there no proofs in Scripture, (they are most numerous and clear), yet nature herself exhorts us to return thanks to God for having brought us forth into light, granted us the use of it, and bestowed upon us all the means necessary for its preservation."

29 John H. Leith, Introduction to the Reformed Tradition (Atlanta: Westminster John Knox Press, 1977, 1981), 198.

30 Henry R. van Til, The Calvinistic Concept of Culture (Philadelphia: Baker, 1959, 1972), 192. 
The Word that became flesh and dwelt among us, the Son who does the work of the father in the world of creation, has entered into a human culture that has never been without his ordering action. ${ }^{31}$

Kristus mau untuk berinkarnasi ke dalam dunia materi dan kesementaraan ini. Hal itu menandakan bahwa kebudayaan dalam dunia materi dan kesementaraan ini amat sangat penting. Penebusan itu bukan hanya menyangkut aspek jiwani-non-material dan dengan demikian kita hanya pasif saja di dunia ini, menunggu waktu masuk surga; melainkan menyangkut aspek material dan dikerjakan dalam kesementaraan sehingga kita memiliki tugas untuk mengerjakan transformasi budaya di dalam dunia materi dan kesementaraan ini.

Mandat budaya bukanlah suatu mandat yang baru diberikan sesudah penebusan, melainkan telah diberikan sejak penciptaan manusia. Hanya saja kita telah mengkhianati Tuhan sehingga perlu penebusan. Maka setelah penebusan, kita memiliki tugas ganda yaitu mentransformasi budaya yang telah rusak (tugas restoratif) dan juga memelihara dan mengembangkan budaya (seperti perintah Tuhan untuk tend and cultivate the Garden). Berita Injil (yaitu penebusan seluruh ciptaan, di dalam Kristus-bukan berarti semua manusia selamat atau penebusan Kristus juga tersedia bagi Iblis!) tidak hanya merupakan jawaban bagi problema eksistensial manusia (restoratif), seperti kata Tillich; tetapi juga merupakan pembaruan panggilan kita untuk, mewakili Allah, berkuasa atas ciptaan (konstruktif). ${ }^{32}$ Tetapi penebusan ini belumlah mencapai titik konsumasinya. Untuk itu saat ini, 'segala mahluk sama-sama mengeluh dan sama-sama merasa sakit bersalin' ketika kita 'dengan sangat rindu seluruh mahluk menantikan saat anak-anak Allah dinyatakan.' ${ }^{33}$ Dalam masa penantian ini umat manusia menciptakan sistem-sistem eskatologinya sendiri. Eskatologi berkait erat dengan bagaimana kita hidup dalam masa penantian itu.

\footnotetext{
Ibid.

Marshall, Heaven is not My Home, 19.

Rm. 8: 22, 19.
} 
Eskatologi adalah kunci bagi etika Kristen. ${ }^{34}$ Sayangnya, beberapa pemikir Kristen cenderung memisahkan eskatologi dari etika. Eskatologi dipandang hanya berkaitan dengan dunia 'nanti dan di sana' sedangkan etika mengurusi hal-hal yang ada 'sekarang dan di sini.' Walau demikian, etika yang diajarkan Yesus sesungguhnya sangat bersifat eskatologis. ${ }^{35}$ Eskatologi dalam PB sesungguhnya bukan sekedar tempelan di akhir teologia sistematik, yang hanya membicarakan 'dunia seberang' dan 'hari-hari akhir,' yang tak ada hubungannya dengan kini dan di sini (here and now). Sesungguhnya seluruh kekristenan bersifat eskatologis. Hal ini tercermin pesan utama dalam setiap zaman yang berpusat pada janji Tuhan, mulai dari Adam sampai rasul Yohanes. Eskatologi itu sendiri tak hanya dapat dipandang sebagai disiplin ilmu yang berkenaan dengan 'hari-hari akhir,' sebaliknya, ia dapat juga dipandang sebagai sebuah diskusi mengenai babak yang baru dari keseluruhan ciptaan. ${ }^{36}$ Dengan demikian diskusi mengenai eskatologi akan mewarnai setiap perdebatan etis. Seperti dikatakan Helmut Thielicke: "Theological ethics is eschatological or it is nothing. "37

Sepanjang sejarah kita menemui ada dua orientasi eskatologis, yaitu konservatisme dan progresivisme. ${ }^{38}$ Seperti dikatakan oleh J. Moltmann,

The feeling, thinking, and desiring of modern men and women are dominated by these two eschatological paradigms. Out of the one has developed what we may call here the conservative syndrome and out of the other what we shall call the progressive syndrome. All the political and ethical decisions of the last 150 years, as of the present day, have been-and still are-determined by one or the other of these syndromes. ${ }^{39}$

\footnotetext{
34 Ini adalah tesis utama dari karya Carl E. Braaten, Eschatology and Ethics (Minneapolis: Augsburg, 1974).

35 Braaten, Eschatology and Ethics, 107.

36 Jurgen Moltmann, "Liberating and Anticipating the Future" dalam Liberating Eschatology: Essays in Honoring of Letty Russell, ed. Margaret A. Farley and Serene Jones (Louisville: WJKP, 1999), 189.

37 Braaten, Eschatology and Ethics, 107.

38 Moltmann, "Liberating and Anticipating the Future", 190.

39 Ibid.
} 
Kini kita akan melihat kedua jenis orientasi ini secara lebih mendetil.

\section{Konservatisme dan Progresivisme}

Mereka yang konservatif, secara definitif tidak menyukai perubahan. Mereka mengharapkan segala sesuatunya tetap seperti semula. Setiap perubahan dianggap sebagai ancaman bagi kestabilan. Mereka hidup di masa lampau. Barangkali mereka adalah orang-orang yang yang selalu mengeluhkan zaman sekarang yang tidak sebaik masa lalu yang serba lebih damai dan teratur. Ciri sindroma konservatif, adalah: ia yakin dunia akan menuju kekacauan, dan itu menakutkan baginya. Maka ia cenderung akan membela status quo dan anti-revolusi. ${ }^{40}$ Antropologinya sangat negatif. Manusia dipandang liar dan destruktif, sehingga harus dikekang oleh institusi pemerintahan yang kuat dan represif (Hobbesian). Institusi-institusi monoteistik, monarki, dan monogami, yang mendorong orang untuk tunduk di bawah trinitas: Tuhan, raja, dan keluarga, adalah manifestasi dari sindroma ini. ${ }^{41}$ Mereka sangat curiga dan merasa terancam dengan perubahan dan gerakan-gerakan pembebasan. Konsekuensi logisnya adalah kelompok ini mengembangkan eschatology of the catechon, yaitu penundaan atau penahanan. ${ }^{42}$ Seperti kekristenan di zaman Konstantin yang menggantikan doa kekristenan purba, "Maranatha, datanglah ya Tuhan Yesus, datanglah segera," dengan doa "pro mora finis"-permohonan agar kiamat ditunda. ${ }^{43}$ Kiamat dipandang sebagai akhir dari keteraturan, yaitu saat terjadinya perang Armageddon antara 'kekuatan Tuhan' yang menghendaki keteraturan dengan kekuatan yang menghendaki

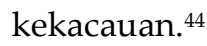

Kebalikan dari konservatisme, progresivisme memuja perubahan baru (change and novice) dan memandang rendah tradisi. Kita dapat

\footnotetext{
$40 \quad$ Ibid., 191.

$41 \quad$ Ibid., 191.

42 Ibid., 193.

43 Ibid., 193.

44 Ibid., 193.
} 
membandingkan konservatisme dengan sikap orang tua yang cenderung curiga terhadap perubahan dan progresivisme dengan sikap anak muda yang cenderung benci dan bosan terhadap segala sesuatu yang telah mapan dan melahap setiap hal baru dengan antusias.

Progresivisme merupakan inti dari semangat modernisme, yang telah melanda manusia sejak renaissance. Seperti telah kita lihat dalam bab 2, sebelum renaissance orang tak berdaya menghadapi segala ancaman dari alam. Masa depan tak dapat ditebak, apalagi dikendalikan atau diarahkan. Masa depan dianggap berada sepenuhnya di tangan Tuhan. Manusia hanyalah aktor-aktor dalam panggung sejarah yang skenarionya telah ditentukan lebih dulu oleh para dewa ataupun Tuhan. Tetapi sejak sains menggantikan teologia, teknologi menggantikan sakramen, dan ilmuwan menggantikan imam; manusia menukar misteri masa depan dengan prediksi saintifik yang hampir 100\% ada di tangan manusia. Dengan demikian manusia dapat mengarahkan jalan hidupnya sendiri, dengan sains sebagai mata yang dapat menembus kekelaman masa depan dan teknologi sebagai tongkat bertuah yang dapat melakukan apapun, sejauh imajinasi manusia.

Pembalikkan peran manusia dari pasif menjadi aktif ini berkait erat dengan gagasan 'resiko.' Gagasan inilah yang membelah era modern dari era pra-modern. Seperti dikatakan Peter L. Bernstein,

Gagasan revolusioner yang merumuskan batas antara masa modern dan masa lalu adalah penguasaan resiko: dugaan bahwa masa depan itu lebih luas daripada sekedar tingkah dewa-dewa, dan bahwa orang tidaklah pasif menghadapi alam. Sampai dengan manusia menemukan jalan untuk menyeberangi batas itu, masa depan masih dianggap sebagai cermin masa lalu, atau wilayah suram dari dukun dan tukang ramal yang memegang monopoli atas pengetahuan tentang peristiwa masa depan..$^{45}$

Bagi Anthony Giddens, masyarakat pra-modern tidak mengenal (dan memerlukan) gagasan resiko, karena

45 Peter L. Bernstein, Against The Gods (New York: John Wiley and Sons, 1996, 1998), 1. 
Kata "risiko" dipergunakan secara luas hanya dalam masyarakat yang berorientasi ke masa depan - yang melihat masa depan dengan tepat sebagai wilayah yang harus ditaklukkan atau dikuasai. Risiko mengandaikan sebuah masyarakat yang secara aktif berusaha melepaskan dirinya dari masa lalu - ini memang merupakan ciri utama peradaban modern. ${ }^{46}$

Orientasi masyarakat pra-modern adalah pada kekekalan. Masa kini dipandang hanya sebagai ekstensi dari kekekalan. Kekekalan dipandang sebagai ketidak-berubahan. Kekinian yang berlangsung selamanya. Masyarakat konservatif memandang perubahan sebagai ancaman atas kestabilan dan keteraturan, tetapi masyarakat modern memandang perubahan sebagai agen kemajuan yang intinya adalah penciptaan masa depan sesuai keinginan dan kehendak bebas manusia. Modernisme ditandai dengan obsesi terhadap kemajuan dan masa depan. Modernisme memberontak dari takdir Tuhan dan para dewa. Hal ini dimungkinkan oleh perkembangan sains dan teknologi yang memperluas kendali kita atas alam. Dalam situasi seperti inilah lahir gagasan resiko,

Risiko adalah dinamika penggerak masyarakat yang cenderung berubah, yang ingin menentukan masa depannya sendiri ketimbang menyerahkannya pada agama, tradisi atau perlakuan alam. ${ }^{47}$

Gagasan 'resiko' dan orientasi ke masa depan juga adalah ciri utama yang membedakan kapitalisme modern dari sistem ekonomi tradisional. Seperti dikatakan Giddens,

Kapitalisme menempatkan dirinya di masa depan dengan menghitung keuntungan dan kerugian yang akan diperoleh, dan karena itu risiko, sebagai proses yang berkelanjutan. ${ }^{48}$

Gagasan bahwa kita dapat mengendalikan masa depan, sehingga tak harus menyerahkannya pada Sang Nasib terwujud secara gemilang

\footnotetext{
46 Anthony Giddens, Runaway World: Bagaimana Globalisasi Merombak Kehidupan Kita (Jakarta: Gramedia, 2001), 18.

47 Ibid., 20

48 Ibid.
} 
setelah Pascal dan Fermat merumuskan teori probabilitas sebagai jawaban atas problem yang diajukan Chevalier de Mere. Problem yang diajukan Chevalier adalah problem klasik yang telah diajukan Luca Paciolli di tahun 1494, dua abad sebelumnya,

A dan B memainkan peran permainan balla. Mereka setuju terus main sampai salah satunya menang enam kali. Permainan ini akhirnya berhenti ketika A memenangkan 5 kali dan B tiga kali. Bagaimana pembagian barang atau uang taruhannya? ${ }^{49}$

Kunci jawabannya terletak pada kuantisasi peluang A dan B dalam memenangkan permainan itu sampai salah seorang dari mereka berhasil memenangkannya enam kali. Agar adil, pembagian uang taruhan haruslah sebanding dengan peluang kemenangan di saat permainan terhenti. Masalahnya adalah kita harus dapat menghitung berapa peluang kemenangan A dan B secara analitis, bukan mencatat hasil eksperimentasinya. Pascal dan Fermat menemukan bahwa problema ini dapat dipecahkan tanpa mengetahui dengan pasti siapa yang akan menang pada putaran berikutnya (dan dengan demikian mensyaratkan kita untuk mengetahui masa depan secara pasti). Pembagian hasil hanya mensyaratkan kita untuk dapat menghitung peluang masing-masing pemain pada tiap putaran. Suatu kuantisasi ketidak-pastian masa depan. ${ }^{50}$

Pascal dan Fermat tidak menemukan satu cara untuk meramalkan masa depan secara pasti, tetapi seperangkat aturan untuk memetakan dan memanajemeni ketidak-pastian masa depan. Konsekuensinya luar biasa. Sebagaimana dikatakan Bernstein,

Tanpa adanya teori probabilitas dan instrumen lain untuk manajemen risiko, para insinyur tidak pernah mampu membangun jembatan kokoh yang membentang di sungai lebar, rumah-rumah di negeri empat musim tetap dihangati dengan tungku api atau kompor besar, fasilitas pembangkit listrik tidak akan ada, polio akan tetap menghantui anak-

49 Bernstein, Against The Gods, 43.

50 Ibid., 10-11. 
anak kita, tidak ada pesawat terbang yang melintas di atas rumah kita, dan perjalanan luar angkasa pun tetap menjadi impian. ${ }^{51}$

Masa depan memang tak dapat diprediksi dengan pasti, tetapi mengetahui berapa ketidak-pastian (dan kepastian) yang kita miliki membawa perubahan dramatis. Kemampuan untuk memanajemeni ketidak-pastian masa depan telah membawa masyarakat modern untuk menanggalkan eskatologi konservatisme dan mengenakan progresivisme sebagai kerangka sistem nilai dan orientasi seluruh hidupnya.

\section{Kesulitan Konservatisme dan Progresivisme}

Kedua orientasi eskatologi ini menimbulkan beberapa kesulitan yang tak terpecahkan kecuali jika kita mengganti paradigma yang dipakai untuk menyusun eskatologi itu. Konservatisme mengandung kesulitan bahwa ia anti-kemajuan. Konservatisme cenderung curiga terhadap perubahan apapun, karena dianggap mengancam keteraturan. Bagi para konservatis Tuhan selalu berada di pihak status quo, dan barangsiapa berusaha membawa perubahan, ia adalah agen Iblis, sang pengacau. Ketegangan antara kaum konservatis dan mereka yang berusaha mereformasi status quo tidak akan dapat diredam selamanya. Ketegangan itu akan memuncak dalam perang apokaliptis yang akan mengakhiri segala sesuatu dan memisahkan pihak status quo dengan pihak 'pengacau.' ${ }^{2}$ Karena ketegangan antara kedua pihak ini bersifat apokaliptis, maka barangsiapa berusaha mendamaikan kedua belah pihak, ia termasuk dalam golongan 'kompromis,' dan dengan demikian tidak berada di pihak 'Tuhan.' Pemisahan di hari akhir menuntut pemisahan tanpa kompromi di saat ini antara 'yang baik' dan 'yang jahat.' 53 Pemisahan tanpa kompromi ini berakibat pada permusuhan antar umat manusia, padahal "perjuangan kita bukanlah melawan darah dan daging, tetapi melawan penguasa-penguasa kerajaan angkasa."

\footnotetext{
51 Ibid., 11.

52 Moltmann, "Liberating and Anticipating the Future", 193.

53 Ibid.
} 
Progresivisme mengandung kesulitan ia telah menutup ruang bagi perkembangan lebih lanjut. Seperti kata Auguste Comte, sejarah telah mencapai titik konsumasi dan mulai memasuki 'perdamaian abadi.' 54 Dengan penguasaan masa depan oleh perangkat matematika probabilitas, manusia telah mengkonsumasi sejarahnya sendiri. Sesungguhnya masa post-historie seperti ini adalah impian eskatologis manusia mulai dari citacita utopis Aufklarung sampai era keemasan sosialisme yang dicitacitakan Marx. Ciri-ciri masa ini adalah: tidak ada lagi kekerasan sehingga institusi perang sepenuhnya diganti institusi perdagangan, edukasi dan kemakmuran bagi semua orang, moralitas dan kemanusiaan tumbuh subur, hirarki dan pemaksaan dapat dihapuskan selamanya. ${ }^{55}$ Ada dua masalah di sini: Pertama, tidak ada masa depan di dalam post-historie. Hari-hari di dalam zaman sesudah 'akhir zaman' ini hanyalah perpanjangan dari masa kini, tanpa akhir. ${ }^{56}$ Kedua, tidak ada lagi tempat bagi Tuhan atau 'Sang Trasenden' yang lain. Dalam semua sistem eskatologi progresif, seperti Hegelianisme, Marxisme, sampai Fukuyama, pada dasarnya tidak ada tempat bagi pengaturan 'dari atas ke bawah' secara hirarkis. Manusia diharapkan untuk mengatur dirinya sendiri secara spontan sebagai jejaring organisme kompleks. ${ }^{57}$ Kebebasan menjadi kutuk. Manusia tak lagi tahu harus menuju ke mana dan melawan apa. Kebebasan dari Sang Transenden yang kita idam-idamkan itu akhirnya membawa kita kepada kekosongan dan pelarian diri, karena bagaimanapun juga kita tak dapat menyangkali kebutuhan akan otoritas dan kenyataan adanya struktur yang masih saja kita perlukan untuk mengatur masyarakat. ${ }^{58}$

\footnotetext{
Ibid., 194.

Ibid.

Ibid., 196.

Francis Fukuyama, The Great Disruption (NY: Profile Books, 1999), 187-211.

58 Robert N. Bellah, et. al., Habits of the Heart: Individualism and Commitment in American Life (Berkeley: UCP, 1985), 23-25.
} 
Alternatif bagi Konservatisme dan Progresivisme: Eskatologi yang Alkitabiah

Alkitab memberikan visi eskatologi yang mengatasi kebuntuan progresivisme dan konservatisme. Visi ini dimulai dari penekanan antropologi Alkitab tentang batas-batas kemanusiaan kita dan ketergantungannya pada Pencipta: manusia bukanlah Tuhan. Seluruh proyek Aufklarung yang menggeser Sang Transenden dari panggung sejarah telah terbukti hanya membawa kita ke dalam jalan buntu. Tuhan orang Kristen adalah Tuhan yang kreatif. Ia menciptakan masa depan yang terbuka bagi ciptaan. Ia memberikan janji pengharapan bagi mereka yang sekarang tertindas oleh rezim konservatif. ${ }^{59}$ Yesus adalah Sang radikal yang membongkar segala kedok putih golongan status quo yang menindas.60 Ia tidak anti perubahan, bahkan Ia adalah agen pembawa perubahan radikal dalam hidup menusia berdosa. Ia juga menyediakan masa depan yang sama sekali lain daripada yang dapat kita bayangkan sekarang, sehingga hal ini mengatasi kebuntuan progresivisme. ${ }^{61}$ Bagian kita dalam masa advent ini adalah mengantisipasi kedatangan hari Tuhan dengan bertindak selaras dengan penggenapan janji Tuhan itu.62 Etika yang diwarnai semangat penantian kedatangan Tuhan yang akan menggenapkan ciptaan ini selaras dengan etika Yesus yang memerintahkan kita untuk senantiasa berjaga-jaga. ${ }^{63}$ Masalahnya: apa yang kita nantikan. Masa depan seperti apa yang dijanjikan Tuhan bagi ciptaan? Ini adalah pertanyaan yang akan sangat menentukan bagaimana kita berjaga-jaga. Bagaimana kita berjaga-jaga adalah bagaimana kita bekerja hari ini. Miroslav Volf mengatakan bahwa bagaimana nasib ciptaan secara keseluruhan akan menentukan bagaimana kita bekerja sekarang,

\footnotetext{
59 Moltmann, "Liberating and Anticipating the Future", 196-198.

60 R. T. France, Yesus Sang Radikal: Potret Manusia yang Disalibkan (Jakarta: BPK, 2000), 93100.

61 Moltmann, "Liberating and Anticipating the Future", 196-198.

62 Ibid., 202-205.

63 Luk. 12: 37.
} 
The question of continuity or discontinuity between present and future orders is a key issue in developing a theology of work. ${ }^{64}$

Ada dua pilihan eskatologis tentang nasib akhir dari dunia ini, yaitu: penghancuran dunia (anihilatio mundi) dan transformasi dunia (transformatio mundi). ${ }^{65}$ Pilihan pertama, yang mengajarkan bahwa dunia ini akan berakhir dengan hancurnya segala keberadaan, jelas akan membuat kerja di dalam dunia material ini tidak bermakna, sejauh itu tidak berkaitan dengan jiwa dan kekekalan. Sedangkan pilihan kedua, yang mengajarkan bahwa segala keberadaan akhirnya akan ditransformasi secara total dalam kesempurnaan, akan menyediakan ruang bagi makna kerja di luar kaitannya dengan hal-hal imaterial. Kita melihat dua contoh dalam pengajaran dua bapak gereja yang dalam hal ini saling bertentangan.

Tertullian (160-220 AD) mengajarkan bahwa dunia ciptaan Tuhan ini akan berakhir di dalam ketiadaan. Sebagaimana Tuhan menciptakan semesta dari ketiadaan (creatio ex nihilo), Tuhan akan mengakhiri semesta menuju ketiadaan. ${ }^{66}$ Konsekuensi logis dari anihilatio mundi adalah tidak ada tempat bagi kegiatan publik (politik) dalam kehidupan Kristen. Mengenai hal ini Tertullian menyimpulkan dengan kalimatnya yang terkenal: nec ulla magis res aliena quam publica. ${ }^{67}$ Di zaman reformasi, Luther juga memiliki pandangan eskatologi anihilatio mundi68. Mungkin ini adalah salah satu penyebab spiritualitasnya yang cenderung bersifat sentripetal dan kurang berperan aktif dalam membentuk struktur sosialpolitik.

\footnotetext{
64 Volf, Work in the Spirit, 89.

65 Ibid., 89-92.

66 Tertullian, Against Hermogenes sebagaimana dikutip oleh Colin E. Gunton, The Triune Creator: A Historical and Systematic Study (Grand Rapids: Eerdmans, 1998), 55.

67 Terjemahan bahasa Inggrisnya adalah: no matter is more alien to us than what matters publicly. Sebagaimana dikutip di dalam, Hannah Arendt, The Human Condition (Chicago: UCP, 1998), 74 .

68 Jurgen Moltmann, The Coming of God: Christian Eschatology (Minneapolis: Fortress, 1996), 274 .
} 
Berlawanan dengan Tertullian, Irenaeus (meninggal 202 AD) percaya pada kebaikan ciptaan dan radikalitas penebusan Kristus yang menebus seluruh ciptaan yang semula baik tapi sudah jatuh secara radikal itu. ${ }^{69}$ Bagi Irenaeus, eskatologi tidak mungkin membatalkan ciptaan Tuhan yang baik itu. Eskatologi, sebagai tujuan akhir seluruh ciptaan, justru harus mengkonfirmasi kebaikan ciptaan di dalam konsumasi. Irenaeus mengatakan bahwa pada tahap penciptaan peta dan teladan Tuhan di dalam Adam 'belumlah sempurna.' Kesempurnaan itu tergenapi secara penuh sesudah penebusan dan konsumasi. ${ }^{70}$ Eskatologi Irenaeus didukung oleh kenyataan bahwa Tuhan sendiri yang mengapresiasi ciptaan sebagai 'baik' dan Anak-Nya yang berinkarnasi ke dalam dunia material ini. ${ }^{71}$ Sikap Irenaeus yang sangat positif terhadap kebaikan ciptaan ini diteruskan oleh Calvin di zaman reformasi ${ }^{72}$ dan menghasilkan sikap khas Calvinistik yang aktif terlibat di dalam membentuk kebudayaan.

Di dalam memilih di antara kedua alternatif ini, tentu kita ingin memprioritaskan posisi yang lebih didukung oleh alkitab, terlepas dari konsekuensinya. Posisi mana yang akan kita pilih? Seperti kata Braaten, tak ada gunanya kita ikut serta dalam pertengkaran antara kubu yang mengatakan bahwa Injil hanya berurusan sepenuhnya dengan urusan dunia 'sekarang dan di sini' dan kubu yang mengatakan bahwa Injil hanya berurusan dengan 'rumah di seberang sana,' karena isi dari Injil adalah kekuatan Allah di dalam Kristus untuk,

... mediate the newness of the coming kingdom into the frame of this present world, to change it from within and through the historical sequence of events. The gospel is the event that keeps this world and the coming kingdom from separating into two opposite worlds, one coming after the other, so that even now there is an overlapping of the old by the new, until

\footnotetext{
69 Colin E. Gunton, The Triune Creator: A Historical and Systematic Study (Grand Rapids:

Eerdmans, 1998), 52-53.

70 Ibid., 200-206.

71 Ibid., 52.

72 Moltmann, The Coming of God: Christian Eschatology, 274.
} 
finally the old shall fade away to reveal the glory of God on the face of a totally new reality. ${ }^{73}$

\section{Bagaimana Alkitab mempengaruhi Cara Pandang Dunia Kita}

Sistem worldview yang kita pakai sebagai kerangka tafsir dalam memandang keseluruhan realitas sangatlah menentukan bagaimana kita memandang aspek-aspek yang lebih spesifik di dalam hidup kita, seperti misalnya kerja. Kerangka tafsir yang telah dipakai orang Kristen untuk memandang realitas hidupnya seringkali tidak alkitabiah. Ada beberapa penyimpangan yang umum terjadi sepanjang sejarah, semisal: gnostisisme, klerikalisme, epistemologi dualistik, sampai pandangan tentang waktu yang memandang rendah kekinian dan kesementaraan dibandingkan dengan 'kekekalan.' Hal ini bersumber pada ketidakpercayaan pada kebaikan ciptaan sebagaimana dideklarasikan YHWH sendiri dalam pasal pertama kitab Kejadian dan ke-sempit-an pengertian akan khasiat penebusan Kristus.

Saya percaya hanya cara pandang yang sepenuhnya kembali kepada alkitab secara totalitas (prinsip sola scriptura, tota scriptura dari gerakan Reformasi) yang akan dapat memimpin hidup manusia kembali kepada kelimpahan dan kedalaman yang direncanakan Tuhan sejak semula. Untuk itu kita akan berangkat dari doktrin Allah. Titik berangkat ini bukanlah sesuatu yang baru. Musa bertolak dari pengenalannya akan nama YHWH ("I AM that I AM") menuju eksodus terbesar dalam sejarah umat manusia. Hal ini tercermin dalam pertanyaan Musa ketika hendak berangkat menemui Firaun, "Siapakah Nama-Mu?" Calvin membuka Institutio-nya dengan mendiskusikan tentang pengenalan akan Allah dan diri sendiri. Sesungguhnya Calvin memakai kedaulatan Allah (sovereignty of God) sebagai titik tolak seluruh usaha teologianya, tidak seperti Luther yang bertolak dari pembenaran melalui iman (justification by faith). Dengan demikian Calvin memiliki cakupan konseptual yang lebih luas (menekankan penciptaan, kejatuhan, dan penebusan dengan seimbang)

73 Braaten, Eschatology and Ethics, 70. 
daripada Luther (cenderung hanya menekankan kejatuhan dan penebusan).

Seperti telah disadari oleh Calvin, pengenalan kita akan Allah tak pernah dapat dipisahkan dari pengenalan kita akan diri sendiri. Teologi tak dapat dipisahkan dari antropologi. Pemahaman kita akan Allah akan sangat menentukan dan ditentukan oleh pemahaman kita akan diri sendiri. Selanjutnya, siapakah Allah dan bagaimana hubungan-Nya dengan manusia akan sangat menentukan jawaban dari keempat pertanyaan mendasar dalam sistem-sistem worldview, yaitu: Siapakah saya? Dimanakah saya? Apakah yang salah? Dan bagaimana penanggulangannya? Dapat dikatakan, doktrin Allah dan doktrin manusia merupakan pusat yang menentukan seluruh worldview kita. Pengenalan kita akan Allah dan diri menentukan seluruh cara kita memandang dunia. Maka kita akan memulai pembahasan kita tentang worldview alkitab dari konsep Allah-manusia (teologi-antropologi).

\section{Konsep Allah-Manusia}

Dalam survey yang telah dilakukan pada bab 2 kita melihat bahwa konsep Allah-manusia sangatlah mempengaruhi pandangan orang tentang kerja. Hal ini akan diakui baik oleh kalangan ateis yang percaya bahwa kita menciptakan Allah sesuai dengan gambar dan rupa kita maupun oleh kalangan Kristen yang percaya bahwa Tuhan menciptakan manusia sesuai gambar dan rupa-Nya. Konsep tentang keberadaan Sang Pencipta segala sesuatu, Sang Transenden yang mengatasi semua, sesungguhnya terlalu tersebar-luas dan tertanam-dalam pada setiap kebudayaan besar untuk dapat diabaikan begitu saja. Kita akan meneliti beberapa problem dalam pemahaman kita tentang diri Allah dan bagaimana Ia berurusan dengan dunia ciptaan-Nya. Seperti telah kita lihat sebelumnya, kedua faktor ini akan menentukan bagaimana seseorang bekerja dalam kaitan dengan ultimate concern-nya. 


\section{Allah dan Diri-Nya: Trinitas dan Perichoresis}

Dalam The 1992 Bampton Lectures yang berjudul The One, The Three and The Many: God, Creation and the Culture of Modernity, Colin E. Gunton berargumen bahwa konsep Tritunggal dapat menjadi titik tolak yang memecahkan banyak dilema modernisme yang diakibatkan oleh pemahaman relasionalitas yang cacat. Baik para pemikir kuno itu maupun para filsuf enlightenment memiliki kesulitan untuk menghormati partikularitas karena mereka gagal dalam 'mendamaikan' relasi one dan many. Mengenai Tritunggal, Gunton mengatakan bahwa,

An account of relationality that gives due weight to both one and many, to both particular and universal, to both otherness and relation, is to be derived from the one place where they can satisfactorily based, a conception of God who is both one and three, whose being consists in a relationality that derives from the otherness-in-relation of Father, Son and Spirit. ${ }^{74}$

Relasi di antara ketiga oknum Tritunggal ini terlukis secara tepat dalam istilah Yunani dari teologia abad ke-enam, yaitu: perichoresis. Istilah ini berarti,

Setiap Pribadi mengandung kedua Pribadi yang lain, setiap Pribadi meresapi yang lain, satu tinggal dalam yang lain dan sebaliknya. Dalam teologi Latin dipakai rumusan circummincessio ("c" dalam kata ini berarti peresapan aktif satu sama lain) atau circuminsessio ("s" melukiskan saling berada satu dalam yang lain yang sifatnya statis atau ekstatis). ${ }^{75}$

Paradigma Tritunggal adalah paradigma yang dipakai alkitab untuk membangun kosmologi-protologi, epistemologi, eklesiologi, soteriologi, eskatologi, sampai konsep waktu. Paradigma Tritunggal menyediakan ruang bagi monisme dan dualisme, kesatuan dan keberagaman, stabilitas dan dinamika, kekekalan dan kesementaraan, sekarang dan nanti, materi dan rohani.

\footnotetext{
74 Colin E. Gunton, The One, The Three and The Many: God, Creation and the Culture of Modernity (Cambridge: CUP, 1995), 6-7.

75 Leonardo Boff, Allah Persekutuan: Ajaran tentang Allah Tritunggal (Maumere: LPBAJ, 1999), 11.
} 
Allah dan Dunia: Kedaulatan Allah dan Kebebasan

Sistem-sistem yang menjunjung tinggi kontemplasi (vita contemplativa) di atas kerja ternyata berkembang di zaman yang juga memiliki konsep Allah yang sangat Platonik. Seperti dalam konsep Plato dan Aristotle, serta teolog-teolog besar Kristen yang sangat dipengaruhi oleh keduanya: Augustine dan Thomas, Allah digambarkan pasif, tenang, stabil, tak dapat dipengaruhi perasaan-Nya (impassible). ${ }^{76}$ Kebahagiaan tertinggi digambar-kan sebagai suatu keadaan tenang (rest) dimana kita memandangi keindahan wajah Tuhan (beatific vision). ${ }^{77}$

Sebaliknya, sistem yang menempatkan kerja (vita activa) pada tempat yang lebih terhormat dibandingkan dengan kontemplasi ternyata berkembang di zaman yang memiliki konsep Allah yang bersifat aktif, misalnya di zaman renaissance. Pada zaman renaissance dan enlightenment Allah digambarkan sebagai sosok pribadi yang aktif mencipta, menopang ciptaan, dan memberikan mandat kepada manusia untuk ikut serta di dalam memerintah alam semesta. ${ }^{78}$

Sejak enlightenment, emansipasi manusia yang terjadi di masa renaissance berevolusi menjadi deifikasi manusia. Seperti Hawa yang tergoda oleh tawaran si ular untuk menjadi seperti Allah, tahu tentang yang baik dan yang jahat, demikianlah para pemikir enlightenment tergoda untuk menjadi seperti Allah: dapat secara mandiri menentukan yang baik dan yang jahat. Manusia tak lagi merasa memerlukan Sang Transenden, apalagi setelah Nietzsche, Marx, dan Freud sukses dalam meyakinkan zamannya bahwa ide Tuhan diciptakan oleh sang penguasa untuk mempertahankan kekuasaannya (atau dalam kasus Freud: Allah adalah sisa proyeksi masa kanak-kanak kita akan figur ayah). Feuerbach, yang pemikirannya memicu filsafat Marx, dengan berani membalikkan tesis "Allah menciptakan kita sesuai dengan gambar dan rupa-Nya"

\footnotetext{
76 Lih. mis. Aristotle, The Ethics of Aristotle, trans. J. A. K. Thomson (Harmondsworth: Penguin, 1955), 307.

77 Thomas Aquinas, Summa Theologica II, Q CLXXXII, Art.2.

78 Justo L. Gonzalez, The Story of Christianity: The Early Church to The Present Day Vol. 1

(Peabody: Prince, 1999), 369-370.
} 
menjadi "kitalah yang sesungguhnya telah menciptakan Allah sesuai dengan gambar dan rupa kita."79

Dilema ini lahir dari konflik yang terjadi antara kedaulatan Allah dan kebebasan manusia. Dengan paradigma perichoresis kita tak akan menemui konflik seperti ini. Allah Tritunggal adalah Tuhan yang memiliki ruang bagi 'sang-lain.' Kedaulatan dan kebebasan satu oknum tidak membatasi kedaulatan dan kebebasan dua oknum yang lain. Dengan demikian kita dapat memahami penyataan alkitab bahwa Tuhan yang berdaulat adalah Tuhan yang memberikan kebebasan kepada manusia.

\section{Konteks Sosial}

Analisis kita tentang struktur hidup kontemporer akan dibagi menjadi dua bagian besar, yaitu: analisa situasi dan respon orang Kristen di dalam situasi tersebut.

\section{Pergeseran Sosiologis dari Gemeinschaft ke Gesellschaft}

Pergeseran dalam struktur masyarakat tradisional menuju modern dapat digambarkan sebagai apa yang disebut oleh F. Tonnies sebagai pergeseran dari gemeinschaft menjadi masyarakat yang bercirikan sebagai gesellschaft. Di bawah ini akan didaftarkan beberapa faktor di dalam pergeseran sosiologis yang paling berpengaruh pada etika kerja Kristen

\begin{tabular}{|c|c|c|}
\hline & Gemeinschaft & Gesellschaft \\
\hline TEKNOLOGI & $\begin{array}{l}\text { Karena teknologi masih primitif, } \\
\text { pacuan kehidupan relatif lambat. } \\
\text { Nyaris tidak banyak perubahan } \\
\text { hari demi hari, kecuali saat perang } \\
\text { atau bencana alam. Teknologi } \\
\text { rendah juga berarti orang tidak } \\
\text { memiliki kendali yang terlalu } \\
\text { besar atas alam dan hidupnya. }\end{array}$ & $\begin{array}{c}\text { Teknologi membuat } \\
\text { hidup berpacu dengan } \\
\text { sangat cepat. Sepanjang } \\
\text { hidupnya, manusia } \\
\text { modern mengalami } \\
\text { sangat banyak } \\
\text { perubahan dalam waktu } \\
\text { yang sangat singkat. }\end{array}$ \\
\hline
\end{tabular}

\footnotetext{
79 Untuk pembacaan tentang antropologi Marx yang lebih humanis alih-alih deterministik dapat dilihat lebih lanjut di dalam analisa Erich Fromm pada buku Marx's Concept of Man (NY: Frederick Ungar, 1978).
} 


\begin{tabular}{|c|c|c|}
\hline & & $\begin{array}{c}\text { Orang juga memiliki } \\
\text { kendali yang lebih besar } \\
\text { atas alam dan hidupnya. }\end{array}$ \\
\hline $\begin{array}{l}\text { STRUKTUR } \\
\text { SOSIAL }\end{array}$ & $\begin{array}{l}\text { Struktur masyarakat masih } \\
\text { bersifat hierarkis-statis. Relasi- } \\
\text { relasi berdasarkan kekerabatan } \\
\text { atau lokasi geografis yang } \\
\text { berdekatan. Relasi-relasi } \\
\text { berjangka panjang, bahkan lintas } \\
\text { generasi. }\end{array}$ & $\begin{array}{c}\text { Struktur masyarakat } \\
\text { berbentuk network yang } \\
\text { setara dan sangat cepat } \\
\text { berubah. Relasi-relasi } \\
\text { pada umumnya berumur } \\
\text { pendek dan bersifat } \\
\text { fungsional. }\end{array}$ \\
\hline $\begin{array}{l}\text { KEBUDAYAAN/ } \\
\text { ANTROPOLOGI }\end{array}$ & $\begin{array}{l}\text { Mono-kultur. Umumnya tidak } \\
\text { pernah melihat atau mengalami } \\
\text { benturan peradaban. Media massa } \\
\text { yang tersedia hanyalah perayaan- } \\
\text { perayaan agama yang hampir } \\
\text { sepenuhnya ada di bawah kontrol } \\
\text { gereja. Tidak ada kebebesan akses. } \\
\text { Akses ke media tulisan hanya } \\
\text { dimiliki sekelompok elit } \\
\text { intelektual yang hampir } \\
\text { semuanya adalah para biarawan } \\
\text { atau petinggi gereja. }\end{array}$ & $\begin{array}{c}\text { Multi-kultur, ada } \\
\text { kesadaran akan } \\
\text { keberagaman peradaban. } \\
\text { Peran media massa } \\
\text { sangat besar dalam } \\
\text { membentuk kesadaran } \\
\text { dan opini publik. Ada } \\
\text { kebebasan akses yang } \\
\text { sangat besar ke dan dari } \\
\text { media massa. }\end{array}$ \\
\hline KONSEP DIRI & $\begin{array}{c}\text { Kesadaran diri sebagai bagian } \\
\text { dari masyarakat dan tradisi masih } \\
\text { sangat kental. }\end{array}$ & $\begin{array}{c}\text { Kesadaran diri sebagai } \\
\text { individu yang bebas } \\
\text { semakin besar. } \\
\text { Menghargai kebebasan } \\
\text { individu lebih daripada } \\
\text { nilai-nilai kolektif dan } \\
\text { tradisi. } \\
\end{array}$ \\
\hline EDUKASI & $\begin{array}{c}\text { Edukasi hanya dinikmati } \\
\text { sekelompok elit. Tidak banyak } \\
\text { orang yang mampu menerobos } \\
\text { keluar dari posisi sosial yang telah } \\
\text { dijalani turun-temurun oleh } \\
\text { keluarganya. }\end{array}$ & $\begin{array}{c}\text { Pemerataan dan } \\
\text { peningkatan efisiensi } \\
\text { dalam edukasi } \\
\text { memungkinkan orang } \\
\text { untuk menguasai banyak } \\
\text { bidang dalam hidupnya. } \\
\text { Jelas menerobos ke } \\
\text { bidang profesi yang baru } \\
\text { sangat dimungkinkan. }\end{array}$ \\
\hline KARIR & $\begin{array}{l}\text { Biasanya hanya terdapat satu atau } \\
\text { sedikit pilihan bagi jalan hidup. } \\
\text { Satu profesi, jabatan, atau jenis } \\
\text { pekerjaan untuk seumur hidup. } \\
\text { Karena teknologi sangat terbatas, } \\
\text { biasanya setiap orang hanya } \\
\text { mampu mengerjakan satu jenis }\end{array}$ & $\begin{array}{l}\text { Ada banyak sekali } \\
\text { pilihan. Teknologi } \\
\text { memungkinkan orang } \\
\text { untuk memiliki dan } \\
\text { mengerjakan banyak } \\
\text { profesi dalam satu } \\
\text { waktu. }\end{array}$ \\
\hline
\end{tabular}




\begin{tabular}{|c|c|c|}
\hline & profesi saja. & \\
\hline & & Jika tidak diarahkan \\
& & dengan hati-hati, \\
& & teknologi dapat \\
& memusnahkan alam. \\
DAMPAK & Teknologi masih belum terlalu & mowerful untuk dapat merusak \\
EKOLOGIS & alam dengan hebat. & duncul krisis ekologi \\
& & dakin tinggi dan merata \\
& & di segala lapisan \\
& & masyarakat. \\
\hline
\end{tabular}

Dalam tabel di atas kita dapat melihat dengan jelas mengapa orang Kristen masa kini mengalami banyak kesulitan untuk menerapkan etika kerja Protestan, yang berkembang pada zaman Luther sampai Puritanisme. Etika kerja Protestan berkembang dan dapat diterapkan dengan sukses di dalam zaman yang masih bercirikan gemeinschaft. Misalnya, penekanan Luther pada profesi $=$ panggilan berkembang di dalam zaman dimana masyarakat bercirikan struktur hierarkis-statis. Pada masa kini, di mana masyarakat lebih berciri gesellschaft yang senantiasa berubah dan memiliki struktur yang sebagian besar bersifat formal saja, orang akan mengalami kesulitan dalam menerapkan anjuran untuk melakukan tugas-tugas dalam masing-masing posisi sosial bagi Allah. Di dalam sebuah gemeinschaft posisi sosial ini memang sulit berubah karena ketidaan akses pendidikan bagi semua orang, alternatif yang relatif sedikit, dan jejaring kroni yang sudah kelewat mengakar. Praktis mustahil bagi seorang petani miskin untuk melintasi batas posisinya dan menjadi seorang bankir atau pejabat negara. 'Impian Amerika' untuk menjadi pahlawan yang berjuang dari nol, 'dari jongos kapal jadi Admiral,' sesungguhnya hampir tidak pernah terjadi di dalam masyarakat abad pertengahan yang memiliki struktur statis.

\section{Refleksi}

Gereja sepanjang dua ribu tahun telah menafsirkan dan menghidupi doa Yesus ini dengan berbagai cara yang sangat beragam, bahkan saling bertolak belakang. R. P. Stevens memberikan tabel 
perbandingan yang dapat memperjelas pemahaman kita akan respon gereja di dalam dunia dalam menangani tarikan antara kebenaran Firman dan situasi dunia tempat tinggal kita. ${ }^{80}$

\begin{tabular}{|l|c|c|c|c|}
\hline Vocation & $\begin{array}{c}\text { Exorcism } \\
\text { Intercession }\end{array}$ & $\begin{array}{c}\text { Suffering } \\
\text { Powerlessness }\end{array}$ & $\begin{array}{c}\text { Creative } \\
\text { Participation }\end{array}$ & $\begin{array}{c}\text { Just } \\
\text { Revolution }\end{array}$ \\
\hline Means & $\begin{array}{c}\text { Spiritual } \\
\text { liberation }\end{array}$ & $\begin{array}{c}\text { Witness to } \\
\text { fallenness }\end{array}$ & Regents & Social changes \\
\hline Metaphysics & Demonic & $\begin{array}{c}\text { Colonized } \\
\text { structures }\end{array}$ & $\begin{array}{c}\text { Fallen and } \\
\text { colonized } \\
\text { structures }\end{array}$ & $\begin{array}{c}\text { Civil } \\
\text { (Marxian) }\end{array}$ \\
\hline Denominations & Charismatic & Anabaptist & $\begin{array}{c}\text { Mainline } \\
\text { (Reformed) }\end{array}$ & $\begin{array}{c}\text { Liberation } \\
\text { Theology }\end{array}$ \\
\hline Authors & $\begin{array}{c}\text { Watson, } \\
\text { Wimber, } \\
\text { Schlier }\end{array}$ & Yoder & $\begin{array}{c}\text { Mouw, } \\
\text { Berkhoff, J. } \\
\text { Ellul }\end{array}$ & $\begin{array}{c}\text { Bonino, } \\
\text { Gutierrez }\end{array}$ \\
\hline
\end{tabular}

Seperti telah disebutkan di dalam bab 2 perbedaan terbesar antara etika kerja Lutheranisme dan Calvinisme adalah: Lutheranisme memandang struktur sosial sebagai konteks tempat kita melayani Tuhan (in vocatione) sedangkan bagi Calvin struktur sosial itu sendiri secara an sich adalah pelayanan kepada Tuhan (per vocationem). Hal ini berakar pada spiritualitas Luther yang pasif dalam mengubah struktur sosial. Struktur itu ditetapkan oleh Tuhan sendiri. Seperti ditegaskan oleh Paulus, kita harus tunduk pada pemerintah yang di atas kita karena struktur pemerintahan itu sendiri ditetapkan oleh Allah. ${ }^{81}$ Tugas orang Kristen adalah untuk taat pada struktur itu, dan melayani Tuhan dan sesama di dalam koridor struktur itu sendiri tanpa mengubahnya. Berbeda dengan Luther, Calvin memiliki spiritualitas yang agresif dan extrovert. Calvinisme memiliki ciri khas sebagai agen pengubah kebudayaan dan struktur sosial itu sendiri. Karena struktur sosial itu

\footnotetext{
80 R. Paul Stevens, The Other Six Days: Vocation, Work, and Ministry in Biblical Perspective (Grand Rapids: Eerdmans, 1999), 231.

$81 \quad$ Rm. 13: 1-2.
} 
sendiri merupakan pelayanan kepada Tuhan, maka transformasi struktur adalah panggilan Tuhan bagi gereja. Wujud pelayanan gereja bagi Tuhan di dalam dunia adalah dengan berpartisipasi dalam memimpin dunia, mentransformasi strukturnya agar lebih mendukung rencana Tuhan dalam penebusan dan dengan demikian juga memiliki sikap antisipasi yang benar dalam menyongsong kedatangan Kristus kedua.

\section{Usulan Solusi}

Kita sekarang sampai kepada bagian akhir dari penyelidikan kita. Setelah meninjau permasalahan worldview dan struktur zaman ini, kesimpulannya: bagaimana orang Kristen harus memandang dan menghidupi pekerjaannya? Apa kaitan antara pekerjaannya sehari-hari dengan panggilan Tuhan. Dalam bagian ini saya banyak mengadopsi pemikiran Miroslav Volf di dalam bukunya, Work in The Spirit (Oxford: Oxford University Press, 1991).

\section{Posisi Kerja dalam Kehidupan Kristen}

Robert N. Bellah dalam Habits of the Heart, membagi posisi kerja dalam kehidupan masyarakat modern menjadi tiga bagian, yaitu: kerja sebagai upaya 'mencari nafkah' (job), 'meniti karir' (career), dan 'meresponi panggilan' (calling). ${ }^{82}$ Kita akan menganalisis kerja sebagai karir dan panggilan.

\section{Kerja sebagai Karir}

Hidup untuk kerja; Atau, kerja untuk kerja itu sendiri? Bagi Volf, Alkitab menempatkan kerja sebagai 'dimensi dasar dari eksistensi manusia.' ${ }^{83}$ Dalam narasi Kejadian, Tuhan menciptakan manusia 'untuk berkuasa ...' ini hanya mungkin dicapai lewat kerja. 'Only as working beings - though not exclusively or even primarily as working beings - can

\footnotetext{
82 Bellah, Habits of the Heart: Individualism $\mathcal{E}$ Commitment in American Life, 65-71.

83 Volf, Work in the Spirit, 127.
} 
human beings live in accordance with the intention of their Creator.' ${ }^{\prime 84}$ Ini diperkuat lagi oleh teks, 'sebelum Adam, tidak ada yang mengelola tanah ...' Walau begitu, dosa membuat kerja dihantui kesia-siaan, 'human work is "threatened by failures and wastes of time and often enough comes to nothing." "85

Dalam hubungannya dengan antropologi, pertanyaan kuncinya bukanlah "berapa sentral kerja dalam eksistensi manusia?" tetapi "apa pengaruh kerja bagi kemanusiaan kita?" Dalam situasi kontemporer kita, kerja semakin dipandang bukan hanya sebagai sumber penghasilan, tetapi sebagai wahana pertumbuhan. Pandangan seperti ini dimulai dari Adam Smith. Kerja membentuk identitas diri seseorang. Volf mengerti hal ini dalam kerangka charisma dengan cara: kharisma bukan diperoleh secara pasif 'dari atas,' 86 tetapi secara aktif dalam interaksi dengan situasi yang mengijinkan pembelajaran. Kegiatan belajar akan mengembangkan kharisma lama (2 Timotius 1:6) dan menemukan kharisma baru (1 Korintus 14:12). Penerimaan, pengembangan, dan penggunaan karunia harus disertai pengembangan dari buah Roh (Galatia 5:22).

'My self-development is an end in itself because it is integral to the new creation and hence a good to be affirmed...but ...not self-contained because I as an individual am not self-contained. I can be fulfilled only when the whole creation has found its fulfillment, too. Because I am an essentially social and natural being... ${ }^{87}$

Menanggapi pandangan yang mengatakan bahwa orang tidak cukup dikatakan berkembang di dalam kerjanya, tetapi adalah produk dari kerjanya, misalnya pada pandangan Marx yang mendefinisikan manusia dari aktivitasnya (homo faber) - seperti Hegel (a person = series of his actions), dan Nietzsche ('doer' cuma fiksi yang ditambahkan pada perbuatan - the deed is everything). Volf berpendapat bahwa kita harus

\footnotetext{
$84 \quad$ Ibid.

85 Ibid., 128-129.

86 Ibid., 130.

87 Ibid., 131.
} 
mengakui bahwa orang bisa berkembang melalui pekerjaan, tetapi kita harus menyangkal dengan tegas bahwa orang bisa mendapatkan kemanusiaanya sendiri di dalam kerja. Hanya Tuhan yang memberikan kemanusiaan kita, bukan usaha kita. Maka persekutuan dengan Tuhan (dalam Roh) adalah kunci bagi identitas diri kita. ${ }^{88}$ Dengan demikian justru keinginan untuk menemukan diri di dalam pekerjaan akan membuat orang kehilangan diri dalam alienasi.

\section{Kerja sebagai Panggilan dalam Konteks Zaman Ini}

Walaupun ajaran vocation dari Luther, yang kemudian berkembang lebih lanjut di tangan Calvin dan orang-orang Puritan, pernah berjaya sebagai cara pandang terhadap kerja yang dipakai masyarakat luas di Eropa dan Amerika, ajaran ini harus diakui tak lagi memadai bagi situasi kerja masa kini. Dalam hal apa saja ajaran vocation ini tak lagi memadai? Volf berpendapat ajaran ini memiliki beberapa kelemahan fatal, di antaranya adalah:

Pertama, ajaran vocation cenderung tak peduli (indifferent) terhadap alienasi dalam kerja. Si pekerja dituntut untuk mencukupkan diri dengan stand-nya, ${ }^{89}$ maka 'virtually every type of work can be a vocation, no mater how dehumanizing it might be (provided that in doing the work one does not transgress the commandments of God)' ${ }^{\prime 90}$ Bagi Calvin cakupan panggilan yang luas seperti ini justru memberikan keuntungan karena justru dapat memberikan 'penghiburan satu-satunya bagi orang yang pekerjaannya kotor dan rendah.' 91 Dengan demikian tuntutan untuk menyesuaikan diri hanya diberikan kepada si pekerja, yang harus dapat menemukan 'panggilan'nya dalam kondisi kerja yang bagaimanapun. Hal ini memang dapat memberikan penghiburan dan makna bagi orang yang

\footnotetext{
88 Ibid., 133.

89 Ibid., 106.

90 Max Weber, Protestant Ethics and The Spirit of Capitalism, trans. Talcott Parsons (NY: Charles Scribner's Sons, 1958), 282.

91 John Calvin, Institutes of the Christian Religion, ed. J. T. McNeill (Philadelphia: Westminster Press, 1977), 725.
} 
terjebak dalam pekerjaan yang mengalienasi, tetapi juga menyediakan kondisi mental pekerja yang sangat cocok bagi kelangsungan penindasan kapitalisme.

Kedua, ada kesulitan dalam mengintegrasikan vocatio externa (vocation) yang datang dalam stand seseorang dengan vocatio spiritualis (call) yang datang dari pekerjaan Roh Kudus dan Firman di dalam hati. Kesulitan muncul saat terjadi konflik di antara kedua jenis panggilan ini, sebagaimana seringkali terjadi dalam sistem Luther yang dualistik. ${ }^{92}$ Dalam prakteknya, seringkali terjadi vocation, yang sering disebut Luther sebagai 'Firman di tangan kiri' menelan 'Firman di tangan kanan' yaitu: Injil. ${ }^{93}$ Dengan kata lain, saat terjadi konflik kepentingan antara Injil dan pekerjaan, maka 'kaum awam' akan cenderung memprioritaskan pekerjaan karena adanya efek samping: 'kaum awam' memandang profesi sebagai panggilan primernya.

Ketiga, ajaran kerja sebagai Vocation ini sering disalah-gunakan untuk mendukung status quo yang tidak adil. Para penguasa ekonomi yang lalim akan mengajarkan bahwa kerja yang paling 'membunuh jiwa' - mekanis - sekalipun adalah melayani Tuhan, sehingga desakan untuk mengubah struktur akan dicap sebagai pemberontakan terhadap 'panggilan Tuhan.' Ajaran ini tidak menyediakan sumber daya bagi perubahan situasi yang menindas. ${ }^{94}$ Hal ini dapat kita lihat misalnya pada sikap Luther terhadap pemberontakan petani yang dipimpin Muntzer. Luther memang mengritik tuan tanah yang menindas petani, tetapi ia sangat menentang pemberontakan yang dilakukan petani karena dianggap telah melangkahi kewenangan mereka. ${ }^{95}$ Para petani tidak berwenang untuk merombak pemerintahan, panggilan mereka adalah untuk tunduk pada pemerintah. Dengan demikian etika sosial Luther bersifat quietist-defeatist yang selanjutnya mendorong orang Kristen untuk membiarkan, atau sekurang-kurangnya tidak menentang,

\footnotetext{
92 Volf, Work in the Spirit, 107.

93 Ibid., 108.

94 Ibid.

95 Alister E. McGrath, Sejarah Pemikiran Reformasi (Jakarta: BPK, 1993), 272.
} 
struktur sosial yang tidak adil. ${ }^{96}$

Keempat, ajaran vocation ini tak lagi cocok bagi masyarakat informasi yang sangat mobile dan cepat berubah. ${ }^{97}$ Tuntutan struktur kerja zaman informasi menuntut perubahan yang sangat cepat, orang tak dapat diharapkan untuk memiliki satu jenis pekerjaan saja seumur hidupnya. Struktur kerja zaman informasi memiliki ciri diachronic plurality of employment.98 Situasi zaman tak mengijinkan hal itu. Orangorang modern ini akan merasa terbelenggu jika tak boleh pindah kerja dan diharuskan untuk 'remain in his vocation, and live content with his gift'. 99 Bagi Calvin rasa puas dengan pekerjaan masing-masing ini penting karena manusia dalam keberdosaannya cenderung untuk tidak puas akan kondisinya. ${ }^{100}$ Kita harus ingat bahwa usulan Luther dan Calvin ini muncul dalam konteks masyarakat mediaeval yang memiliki struktur statis dan hierarkis. Jadi, mereka telah memberikan jawaban yang sangat memadai bagi permasalahan kerja di zaman itu, tetapi ketika zaman berubah kemungkinan besar kita tidak dapat lagi memakai jawaban kontekstual ini mentah-mentah.

Kelima, ajaran Vocation dalam bentuknya yang paling konsisten, ${ }^{101}$ menuntut vocatio externa tunggal dengan asumsi: hal ini merupakan keharusan karena Tuhan juga hanya memberikan vocatio spiritualis tunggal. Hal ini berarti seorang pekerja tak boleh memiliki lebih dari satu profesi dalam setiap waktu. Jelas ini tak cocok dengan zaman ini, di mana 'synchronic plurality of employment' menjadi ciri yang penting. Di zaman ini orang biasa untuk menjalani lebih dari satu profesi setiap waktu. ${ }^{102}$

\footnotetext{
$96 \quad$ Ibid., 273.

97 Volf, Work in the Spirit, 108.

$98 \quad$ Ibid., 137.

99 Martin Luther, Martin Luther's Werke, 42, 640 sebagaimana dikutip oleh Volf dalam Work in the Spirit (Oxford: OUP, 1991), 108.

100 Volf, Work in the Spirit, 108.

101 Bagi Luther dalam kenyataannya orang punya lebih dari satu stand, misalnya: ayah, buruh, suami.

102 Volf, Work in the Spirit, 109.
} 
Keenam, ajaran vocation ini, bersama-sama dengan worldview materialistik zaman revolusi industri menghasilkan pemberhalaan kerja, walaupun para reformator pasti tidak pernah memaksudkannya demikian. Prosesnya terjadi sebagai berikut. Akibat revolusi industri, dengan sistem-sistem produksi massalnya yang sangat efisien, labor tidak lagi dipandang hanya menghasilkan pemenuhan kebutuhan dasar fisik. Dengan demikian status labor meningkat,

...for Locke, labor is the source of property, for Smith, it was the source of all wealth and for Marx, it became the source of all productivity and the expression of its very humanity. Locke tries to save labor from its manifest disgrace of producing just the short durable things. ${ }^{103}$

Peningkatan status ini bergabung dengan ajaran vocation yang sudah dipersiapkan Luther pada zaman sebelumnya dan menyebabkan penerapan 'kesungguhan keagamaan dari panggilan monastis itu untuk kegiatan di dalam dunia.' ${ }^{104}$ Dengan menambahkan kepercayaan bahwa vocation merupakan pelayanan utama 'kaum awam' kepada Tuhan, maka, menurut pendapat Volf, pekerjaan berubah status menjadi agama. ${ }^{105}$

Mengingat sumbangsih etika kerja Protestan yang didasarkan pada ajaran vocation Luther dalam menepis pandangan dualistik abad pertengahan tentang kerja, banyak ahli yang ingin melakukan penafsiran kembali ajaran ini agar lebih sesuai dengan konteks kerja modern, tetapi bagi Volf ada argumentasi eksegetikal-teologikal yang tidak mengijinkan kita untuk tetap memakai ajaran ini. Bagaimanapun penafsiran ulang yang kita lakukan, tetap saja hal itu tak akan menghapus kesalahankesalahan fatal yang telah dibuat Luther dalam menyusun ajaran vocation ini.

Menurut Volf, ada dua kesalahan utama yang dibuat Luther dalam ajaran vocation-nya, pertama adalah salah eksegese teks alkitab yang

103 Hannah Arendt, The Human Condition, 101 sebagaimana dikutip oleh Anton Subianto, "Hannah Arendt's Conception on 'animal laborans' and 'homo faber'" dalam jurnal Melintas No. 48, th. ke-15, Des 1999.

104 Alister E. McGrath, Sejarah Pemikiran Reformasi (Jakarta: BPK, 1993), 293

105 Volf, Work in the Spirit, 109. 
dijadikan landasan utama ajarannya, kedua adalah ketidakkonsistenannya dalam memakai istilah vocatio externa dan vocatio interna. $^{106}$ Kesalahan Luther dalam mengeksegese 1 Korintus 7:20 terjadi pada penafsiran istilah 'calling' dalam bagian itu. Istilah ini tidak dapat dimengerti sebagai calling with, calling to, atau calling by di mana seseorang dipanggil, melainkan mengacu pada keadaan pada saat ia dipanggil menjadi orang percaya. Kata klesis (call) itu adalah istilah teknis untuk dipanggil menjadi Kristen, seperti pada 1 Petrus 1:15.107 Jadi ini sama sekali bukan panggilan khusus, tetapi panggilan umum bagi semua orang Kristen. Dengan kata lain teks ini tak dapat dijadikan acuan untuk mendukung ajaran tentang panggilan berupa satu profesi khusus bagi orang percaya.

Mengenai kesalahan kedua, istilah work hanya dapat diidentikkan dengan vocatio externa jika kita dapat mempertahankan analogi antara vocatio interna dengan vocatio externa. Bahkan Luther, yang hidup dalam masyarakat mediaeval yang statis-hierarkis tidak dapat mempertahankan korespondensi kedua macam panggilan ini secara konsisten. Orang dapat saja mengatakan bahwa vocatio spiritualis itu waktu tiba pada tiap individu akan bercabang pada tugas-tugas yang plural, tetapi Volf melihat bahwa pandangan seperti ini tidak sesuai dengan ajaran PB. Hal ini juga sebenarnya tidak kita perlukan karena Perjanjian Baru memiliki istilah teknis sendiri berkaitan dengan panggilan (majemuk) tiap orang Kristen untuk tugas-tugas khusus, yaitu: charisma, atau karunia-karunia Roh. ${ }^{108}$

\section{Konsep Sabat dan Batas dari Kerja}

Sekarang kita akan melihat hubungan antara human needs dan sabbath. Orang bekerja sebagai respon atas kebutuhan (needs), terutama kebutuhan material. ${ }^{109}$ Kerja adalah sarana bagi kebutuhan yang

\footnotetext{
106 Ibid., 109-110.

107 Ibid., 110.

108 Ibid.

109 Ibid., 148.
} 
dirasakan, kebutuhan itu sendiri menjadi tujuan akhir (end). Alkitab sangat realistis dalam hal ini. Kerja tak hanya dipandang sebagai pelayanan kepada Tuhan saja (seperti mitos Babilonia di zaman Alkitab) atau sekedar sarana bagi human self-development (Marx). Alkitab memandang kerja terutama sebagai sarana untuk memenuhi kebutuhan material dari kita dan sesama.

Kebutuhan tidaklah statis. Hal ini membuat masalahnya menjadi rumit. Jika kebutuhan statis, kita hanya perlu memastikan orang yang mampu bekerja tidak hidup dari hasil usaha orang lain, dan orang yang tidak mampu bekerja tetap terpenuhi kebutuhan dasarnya. Waktu kemampuan produksi berkembang, kebutuhanpun berkembang. Inilah sebabnya orang yang bekerja di negara maju, di mana kebutuhan pokok dapat dicukupi dengan jam kerja yang sangat sedikit, tetap saja menghabiskan banyak waktu untuk bekerja. Mereka memenuhi kebutuhan yang semakin banyak. ${ }^{110}$ Kebutuhan yang selalu bertambah ini berakar pada permanent self-transcendence of human beings. ${ }^{111}$ Dampak kebutuhan yang terus bertambah adalah kerusakan lingkungan. Teologia yang benar dalam memahami bumi sebagai ciptaan, atau sebagaimana dikatakan Calvin sebagai 'pakaian kebesaran Tuhan yang terlihat' dan makna perkerjaan manusia sebagai panggilan Tuhan akan berdampak pada cara-cara kita mengelola bumi. Randall Zachman menyatakan kaitan keduanya dengan krisis ekologis yang kita alami:

If we had followed this teaching, would we really have been led to exploit and defile the earth with a good conscience? If we had heeded Calvin's teaching of our responsibilities toward the created world, would we really have been encouraged to gorge ourselves on the good things of the world as though we would never have to render account of our behavior to God? Is the ecological crisis of the Western world due to the fact that too many people followed Calvin's teaching about creation, or is it due to the fact that his teaching was apparently ignored? ${ }^{112}$

\footnotetext{
110 Ibid., 149.

111 Ibid., 150.

112 Zachman, "The Universe as the Living Image of God: Calvin's Doctrine of the Universe Reconsidered", 312.
} 
Soal pembatasan kebutuhan ini berkaitan dengan soal baik-jahat. ${ }^{113}$ Dalam teori Kristen tentang kebutuhan manusia, pembedaan antara kebutuhan yang salah dan benar bukan hanya sesuai hukum, tetapi juga suatu keharusan. Manusia berdosa seringkali merasakan kebutuhan akan sesuatu yang sebenarnya membawa kebinasaan.

Ada banyak cara untuk membatasi kebutuhan, diantaranya adalah: 1) asketisme: problemnya adalah ia menyangkali sifat kebutuhan manusia yang dinamis dan kebaikan ciptaan yang dibuat untuk dinikmati. 2) pembatasan paksa yang dilakukan pemerintah atas struktur kebutuhan manusia. Bagi Ignatieff ini berbahaya karena tak ada orang yang lebih tahu apa yang dibutuhkan seseorang selain dirinya sendiri. ${ }^{114}$ Orang lain mungkin saja lebih tahu tapi masalahnya adalah orang tidak boleh memaksakan pengetahuannya itu pada sesamanya. Hal ini akan menjadi diktatorisme. ${ }^{115}$ Jalan keluar Volf adalah dengan menolong orang untuk menemukan dan mengembangkan fundamental needs yang lain, yang tidak mensyaratkan pemuasannya lewat produksi material. Pemenuhan kebutuhan non-material ini akan berfungsi sebagai pembatas dengan memberikan kriteria product-needs apa-apa saja yang masih dapat dikembangkan dan yang tidak. Dengan begini kita menghargai dinamika kebutuhan dan kebebasan manusia. ${ }^{116}$

Kebutuhan fundamental ini harus berakar secara obyektif pada natur manusia sebagai citra Allah, tetapi dibangkitkan secara subyektif oleh Roh Kudus. Roh yang sama yang memperlengkapi orang bekerja akan memotivasi mereka untuk memuaskan kebutuhan dasar nonmaterial ini, yang pada gilirannya akan membatasi kebutuhan material. Pengertian pneumatologikal akan kerja menolak pemuasan product-needs dengan mengorbankan non-product-needs (konsumerisme) dan juga menolak pemuasan non-product-needs dengan mengorbankan product-

\footnotetext{
113 Volf, Work in the Spirit, 151.

114 Ibid.

115 Ibid., 152.

116 Ibid.
} 
needs (asketisme). ${ }^{117}$

Yang dimaksud dengan fundamental-non-product-needs itu diantaranya: ${ }^{118}$

1. Bersekutu dengan Allah. Makin kita kelaparan makin kita tak merasakan kebutuhan untuk bersekutu dengan Tuhan. Roh akan membangkitkan kerinduan akan Allah, yang memuaskan dahaga jiwa manusia. Dengan demikian, hidup yang melimpah di dalam Tuhan akan menjaga orang dari keserakahan material (Yesaya 55:2).

2. Solidaritas dengan alam. Roh akan menyadarkan orang percaya bahwa alam akan berbagian dalam keselamatan di dalam New Creation, sehingga orang bertanggung-jawab pada alam.

3. Roh akan mempersatukan umat percaya dengan menimbulkan kerinduan untuk bersekutu satu sama lain dalam satu tubuh Kristus, diikat oleh ikatan kasih. (1 Korintus 12:13) Orang akan dibebaskan dari individualisme.

4. Kebutuhan untuk bertumbuh, baik di dalam Moral, maupun ketrampilan praktis dan intelektual. Dalam moral, Roh memberikan buah Roh; dalam ketrampilan praktis dan intelektual, kita wajib mengobarkan karunia Roh.

5. Keempat kebutuhan dasar di atas berakar pada kebutuhan universal yang satu, yaitu: Kebutuhan akan Ciptaan Baru, yaitu Kerajaan Kebebasan. Di dalam Kerajaan Kebebasan ini keempat kebutuhan dasar di atas akan terpenuhi secara tuntas. "Carilah dahulu Kerajaan Allah maka semuanya itu akan ditambahkan kepadamu." (Matius 6:33).

117 Ibid.

118 Ibid., 152-154. 